\title{
Seasonal variability and sources of in situ brGDGT production in a permanently stratified African crater lake
}

\author{
Loes G. J. van Bree ${ }^{1}$, Francien Peterse ${ }^{1}$, Allix J. Baxter ${ }^{1}$, Wannes De Crop ${ }^{2}$, Sigrid van Grinsven ${ }^{3}$, Laura Villanueva ${ }^{3}$, \\ Dirk Verschuren ${ }^{2}$, and Jaap S. Sinninghe Damsté ${ }^{1,3}$ \\ ${ }^{1}$ Department of Earth Sciences, Faculty of Geosciences, Utrecht University, Princetonlaan 8A, \\ 3584 CB Utrecht, the Netherlands \\ ${ }^{2}$ Limnology Unit, Ghent University, K.L. Ledeganckstraat 35, 9000 Gent, Belgium \\ ${ }^{3}$ NIOZ Royal Netherlands Institute for Sea Research, Department of Marine Microbiology and Biogeochemistry, \\ and Utrecht University, P.O. Box 59, 1790 AB Den Burg, the Netherlands
}

Correspondence: Francien Peterse (f.peterse@uu.nl)

Received: 18 June 2020 - Discussion started: 28 July 2020

Revised: 21 September 2020 - Accepted: 5 October 2020 - Published: 13 November 2020

\begin{abstract}
Lake sediments are important archives of continental climate history, and their lipid biomarker content can be exploited to reconstruct paleoenvironmental conditions. Branched glycerol dialkyl glycerol tetraethers (brGDGTs) are bacterial membrane lipids widely used in paleoclimate studies to reconstruct past temperature. However, major gaps still exist in our understanding of the environmental controls on in situ (i.e. aquatic) production in lake systems. In Lake Chala, a permanently stratified tropical crater lake in East Africa, we determined the concentrations and fractional abundances of individual brGDGTs along depth profiles of suspended particulate matter collected monthly from September 2013 to January 2015 and in settling particles collected monthly at $35 \mathrm{~m}$ water depth from August 2010 to January 2015 and compared these brGDGT distributions with those in surficial lake bottom sediments and catchment soils. We find that brGDGTs are primarily produced within the water column and that their concentrations and distributions vary greatly with depth and over time. Comparison with concentration-depth profiles of the monthly distribution and abundance of bacterial taxa, based on 16S rRNA gene amplicon sequencing and quantification, indicates that Acidobacteria are likely not the main producers of brGDGTs in Lake Chala. Shallowing of the oxic-anoxic boundary during seasonal episodes of strong water column stratification promoted production of specific brGDGTs in the anoxic zone. BrGDGT distributions in the water column do not consistently relate with temperature, $\mathrm{pH}$, or dissolved-
\end{abstract}

oxygen concentration but do respond to transitions between episodes of strong stratification and deep (but partial) lake mixing, as does the aquatic bacterial community. Hence, the general link between brGDGT distributions and temperature in brGDGT-based paleothermometry is more likely driven by a change in bacterial community composition than by membrane adaptation of specific members of the bacterial community to changing environmental conditions. Although temperature is not the principal driver of distributional changes in aquatic brGDGTs in this system, at least not during the 17-month study period, abundance-weighted and time-integrated averages of brGDGT fractional abundance in the 53-month time series of settling particles reveal systematic variability over longer timescales that indirectly relates to temperature. Thus, although we do not as yet fully understand the drivers of modern-day brGDGT fluxes and distributions in Lake Chala, our data do support the application of brGDGT paleothermometry to time-integrated archives such as sediments.

\section{Highlights.}

- BrGDGTs in the tropical African lake Chala are produced in situ.

- Acidobacteria are not the dominant source of aquatic brGDGTs.

- Stratification and mixing drive aquatic brGDGT production and their signature. 


\section{Introduction}

Lake sediments are important archives of continental climate history, especially in (sub-)tropical regions where other longterm, high-resolution natural archives such as ice cores are lacking. Lipid biomarkers preserved in those sediments can be used to examine present and past environmental conditions and often provide more specific information on those conditions than bulk geochemical proxies (see Castañeda and Schouten, 2011 for a review). For example, plant waxes stored in lake sediments are used to reconstruct past vegetation and hydroclimate dynamics (e.g. Freeman and Pancost, 2013; Diefendorf and Freimuth, 2017), while the presence and distribution of (iso-)loliolide, long-chain $n$-alk-1-enes, or 1,15 $n$-alkyl diols can be linked to shifts in algal community composition and/or primary productivity (e.g. Volkman et al., 1998; Castañeda and Schouten, 2011; van Bree et al., 2018).

Temperature is probably the most important climate parameter to be reconstructed quantitatively from lacustrine settings. Although temperature variation in the tropics is relatively modest, even on glacial-interglacial timescales (2$4{ }^{\circ} \mathrm{C}$ at sea level; e.g. Loomis et al., 2017; Chevalier et al., 2020), this has major impact on tropical continental rainfall through its control on sea surface evaporation and monsoon dynamics between the ocean and adjacent continents. Therefore, no rainfall or moisture balance reconstruction from the tropics can be properly interpreted without knowing local and regional temperature history as a reference frame. However, despite more than a decade of substantial effort, generating long and continuous quantitative temperature reconstructions from tropical regions remains challenging.

One promising proxy for continental paleothermometry is based on a suite of membrane lipids supposedly derived from bacteria, namely the branched glycerol dialkyl glycerol tetraethers (brGDGTs; Sinninghe Damsté et al., 2000). These consist of tetra- (I), penta- (II), or hexamethylated (III) components, with no (suffix a), one (b), or two (c) cyclopentyl moieties, and with methyl groups on the fifth (5-methyl) or sixth (6-methyl; indicated with a prime notation) carbon position of their alkyl chain (Fig. 1; Sinninghe Damsté et al., 2000; Weijers et al., 2006; De Jonge et al., 2013). The distribution of brGDGTs in modern surface soils and peats shows empirical relationships with mean annual air temperature (MAAT) and the $\mathrm{pH}$ of the soil or peat in which they are produced (Weijers et al., 2007b; De Jonge et al., 2014a; Naafs et al., 2017a, b). Although the bacteria that produce brGDGTs are still largely unknown (Sinninghe Damsté et al., 2018), this relationship has been commonly used as proxy for continental air temperature in paleoclimate reconstructions. For example, analysis of brGDGTs in loess soils, peats, and marine sediments has produced paleotemperature records across a wide range of geological ages (e.g. Weijers et al., 2007a; Peterse et al., 2011; Naafs et al., 2017a; Zheng et al., 2017).

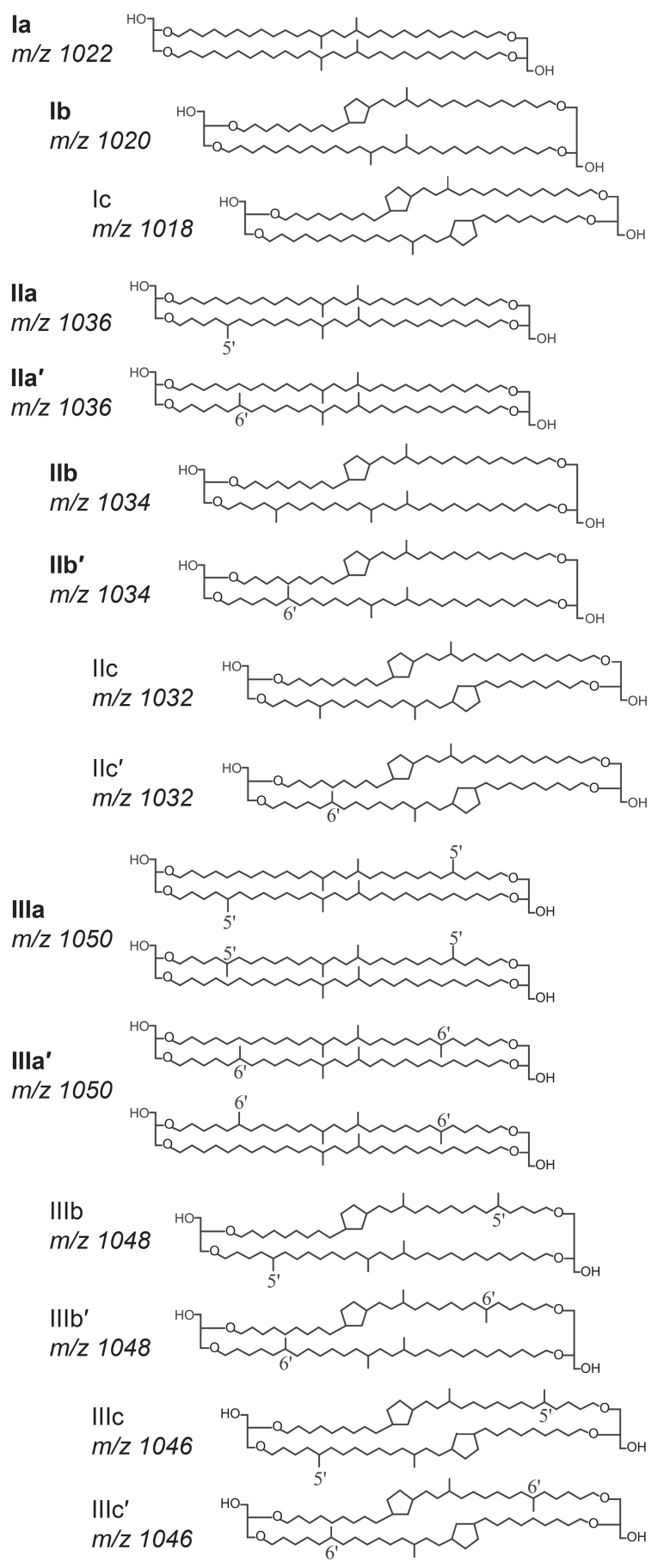

Figure 1. Molecular structures of brGDGTs, consisting of two ether-linked dialkyl chains with zero to two additional methyl branches (I, II and III) and zero to two cyclopentyl moieties (suffixes $a, b$ and c). The 6-methyl isomers are denoted with a prime. Compounds indicated in bold are the eight most common brGDGTs encountered in Lake Chala and focused upon in data presentation and discussion. 
The application of this temperature proxy on lake sediment records was initially based on the premise that all sedimentary brGDGTs are derived from catchment soils and washed into the lake by erosion. However, when brGDGT distributions in lake sediments were found to differ substantially from those in soils surrounding the lake, it became clear that there must also be an in situ source of brGDGTs contributing to the lake sediments (e.g. Tierney and Russell, 2009; Tierney et al., 2010; Sinninghe Damsté et al., 2009; Loomis et al., 2011; Schouten et al., 2013; Buckles et al., 2014; Colcord et al., 2015; Li et al., 2016). In addition, brGDGT isomers of type IIIa with methyl branches at the fifth position on the one end and at the sixth position on the other end ( $\left.\mathrm{IIIa}^{\prime \prime}\right)$ have so far been detected exclusively in lakes and not in soils, providing further evidence for their in situ production (Weber et al., 2015, 2018). Furthermore, lacustrine brGDGTs are significantly more ${ }^{13} \mathrm{C}$-depleted than those in nearby soils, implying that at least some of their sources are distinct (Weber et al., 2015, 2018; Colcord et al., 2017).

Water column studies show that brGDGT concentrations generally increase below the oxycline, suggesting that they are mainly produced in the anoxic portion of the hypolimnion (Sinninghe Damsté et al., 2009; Bechtel et al., 2010; Blaga et al., 2011; Woltering et al., 2012; Buckles et al., 2014; Loomis et al., 2014b; Miller et al., 2018). Further, brGDGT production often varies seasonally (Sinninghe Damsté et al., 2009; Woltering et al., 2012; Buckles et al., 2014), which may introduce a temperature bias towards the season(s) with high brGDGT production (Loomis et al., 2014b; Miller et al., 2018). The contribution of aquatic brGDGTs, especially that of IIIa, generally results in a substantial underestimation of present-day temperature when the transfer function based on soil brGDGTs is used (Tierney et al., 2010), which has stimulated the development of temperature calibrations based on lake sediments (Tierney et al., 2010; Pearson et al., 2011; Sun et al., 2011; Loomis et al., 2012; Russell et al., 2018). As in soils, the amount and distribution of brGDGTs in lake sediments seems to be influenced mostly by temperature and lake-water pH (Tierney et al., 2010; Sun et al., 2011; Loomis et al., 2014a), although a wide range of other factors, such as oxygen availability (e.g. Tierney et al., 2012; Loomis et al., 2014a; Weber et al., 2018), light (Loomis et al., 2014b), mixing regime (Loomis et al., 2014b), nutrients (Tierney et al., 2010; Loomis et al., 2014a), alkalinity (Schoon et al., 2013), redox state (Weber et al., 2018), and conductivity (Tierney et al., 2010), have also been suggested to influence the in situ production of brGDGTs in lakes.

Temperature calibrations based on brGDGTs in soils and peats have substantially improved following the identification and chromatographic separation of 5-methyl and 6methyl brGDGT isomers (De Jonge et al., 2014a; Naafs et al., 2017a, b; Dearing Crampton-Flood et al., 2020). Initial scanning of surficial bottom sediments from East African lakes revealed that especially 6-methyl brGDGTs behave differently in lakes compared to soils, suggesting that they are produced by different bacteria or that brGDGT producers in lakes respond differently to environmental changes than those in soils (Russell et al., 2018). Separation of the 5methyl and 6-methyl brGDGTs yields slightly better error statistics for the East African lake calibration and lacks outliers such as those present in the calibration without separation of these isomers, re-affirming the potential of brGDGTs for paleotemperature reconstructions in lakes (Russell et al., 2018). Nevertheless, Weber et al. (2018) recently showed that variations in brGDGT composition above and below the oxycline in Lake Lugano (Switzerland) are linked to the occurrence of distinct bacterial groups that thrive in the oxic and anoxic parts of the water column. In addition, the carbon isotopic composition of brGDGTs in the sediments of Alpine lakes indicates that brGDGT producers are differentiated according to lake trophic status. Together, this suggests that brGDGT signatures in a lake sediment record may also be influenced by temperature-independent factors, such as variations in community composition and primary production (Weber et al., 2018).

In this study we examined brGDGTs in suspended particulate matter (SPM) from the water column of a permanently stratified lake (Lake Chala) in tropical Africa over a 17-month period to further constrain the seasonal and depth distribution of different brGDGTs, to identify their main producers, and to ascertain the sources of brGDGTs eventually stored in lake sediments. To this effect, the SPM brGDGT data were compared with measurements of temperature, $\mathrm{pH}$, and dissolved oxygen (DO) obtained through concurrent water column monitoring and with the composition and abundance of bacterial taxa in the SPM based on 16S rRNA gene amplicon sequencing and quantification. We also analysed brGDGTs in settling particles collected at monthly intervals over a 4.5-year (53-month) period, to reveal possible long(er)-term trends in the seasonality of brGDGT production in this lake, which may help elucidate its environmental drivers. Finally, comparison of the aquatic brGDGT signature with that of soils surrounding the lake and the lake sediments itself was expected to shed light on the significance of paleoclimate reconstructions based on brGDGTs in lake sediments.

\section{Material and methods}

\subsection{Study system}

Lake Chala (locally "Challa", after a nearby village) is a small $\left(4.2 \mathrm{~km}^{2}\right)$, deep $(\sim 90 \mathrm{~m})$ and permanently stratified (meromictic) crater lake, situated at $\sim 880 \mathrm{~m}$ above sea level and bridging the border of Kenya and Tanzania ( $3^{\circ} 19^{\prime} \mathrm{S}$, $37^{\circ} 42^{\prime} \mathrm{E}$ ) in the foothills of Mt. Kilimanjaro. At this nearequatorial location, mean monthly air temperature (MMAT) varies between $21-22^{\circ} \mathrm{C}$ in July-August and $26-28^{\circ} \mathrm{C}$ in January-February (Buckles et al., 2014; Bodé et al., 2020). 
The tropical rain belt associated with latitudinal migration of the Inter-Tropical Convergence Zone (ITCZ) passes across the region twice yearly, resulting in two wet seasons and two dry seasons. Short rains occur from late October to December, and long rains from March to mid-May. The principal dry season occurs during Southern Hemisphere winter (June-September) and is characterized by lower air temperature and higher wind speeds. The latter drive evaporative cooling which promotes deep convective mixing of the water column of Lake Chala to $\sim 40-60 \mathrm{~m}$ depth, while the deeper water remains permanently stratified and anoxic (Wolff et al., 2011; Buckles et al., 2014; van Bree et al., 2018). A second period of lesser mixing, to 25-30 $\mathrm{m}$ depth, occurs during the short dry season of January-February. Primary productivity is highest during the principal dry season (June to October), when nutrient-rich deep water is mixed upwards into the normally unproductive epilimnion (Wolff et al., 2014; van Bree et al., 2018). The lake's water balance is partly maintained by rainfall on the lake surface and over the steep-sloping crater basin, occasionally supplemented by high rainfall over the catchment of a small creek which breaches the northwestern crater rim (Buckles et al., 2014). As lake surface evaporation (1700 $\mathrm{mm} \mathrm{yr}^{-1}$ ) greatly exceeds annual rainfall $\left(600 \mathrm{~mm} \mathrm{yr}^{-1}\right)$, water balance is maintained by substantial subsurface inflow (Payne, 1970) of water that originates from percolation in or above the forest belt on Mt. Kilimanjaro (Hemp, 2006; Bodé et al., 2020).

\subsection{Field observations and sample collection}

\subsubsection{Temperature, $\mathrm{pH}$ and dissolved-oxygen monitoring of the water column}

Vertical profiles of temperature, dissolved oxygen (DO), conductivity (K25) and $\mathrm{pH}$ were measured at $2 \mathrm{~m}$ intervals through the upper $50 \mathrm{~m}$ of the water column using a Hydrolab Quanta ${ }^{\circledR}$ multi-sensor probe at a mid-lake position (Fig. 2) at monthly intervals between September 2013 and January 2015 (van Bree et al., 2018). Additionally, water temperature was measured by automatic temperature loggers, at 2-hourly intervals between September 2010 and January 2015, suspended at a selection of the following water depths: 2, 10, 20, 25, 30, 35, 40, 45, 50 and $85 \mathrm{~m}$. The set of monitoring depths varied over time due to the occasional malfunctioning and subsequent replacement of loggers. Due to the loss of logger data during retrieval, no water column temperature information is available for the period between 7 January and 11 September 2012. The entire 53-month temperature record was corrected for drift of individual loggers, using the Hydrolab profiles as reference. Periods of water column mixing and stratification were determined on the basis of the temperature logger time series or estimated for the above-mentioned hiatus period on the basis of mean monthly air temperature (MMAT) data from Bodé et al. (2020); the
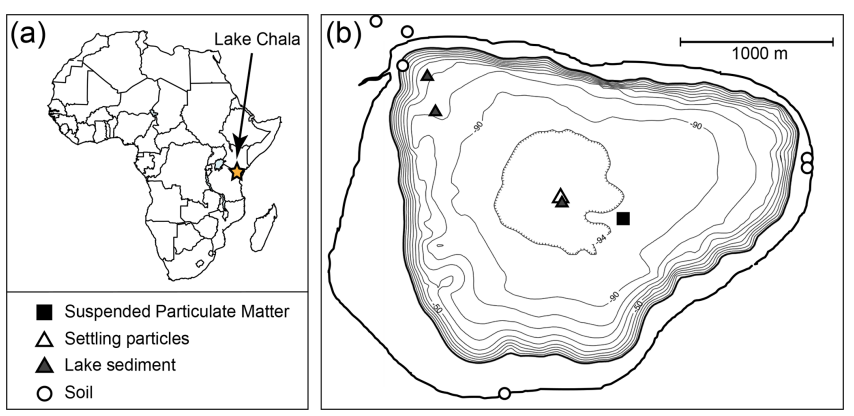

Figure 2. (a) Location of Lake Chala in East Africa, on the border of Kenya and Tanzania, and (b) the bathymetry of Lake Chala situated within its steep-sided crater catchment (outer bold full line), with sampling locations of suspended particulate matter (SPM; black square), settling particles (sediment trap; open triangle), surficial lake-bottom sediments (grey triangles) and terrestrial soils (open circles). Bathymetry adapted from Moernaut et al. (2010).

latter represents a savanna site $\sim 25 \mathrm{~km}$ to the west of Lake Chala and at similar elevation.

\subsubsection{Suspended particulate matter sampling}

Collection of the SPM profiles used in this study has been described by van Bree et al. (2018). In short, 5 to $10 \mathrm{~L}$ of lake water was collected monthly between September 2013 and January 2015 at 13 discrete depths. The samples were filtered on pre-combusted glass fibre GF/F filters (142 mm diameter, Whatman), stored frozen and freeze-dried prior to analysis. The SPM was collected at or near the start of every month as discussed here, with the sample taken at, for example, 07-092013 representing September 2013, and the sample taken at 30-09-2013 representing October 2013 (see Table S1 in the Supplement).

\subsubsection{Sampling of settling particles}

A sediment trap (UWITEC, double-funnelled, $86 \mathrm{~mm}$ diameter) suspended in $35 \mathrm{~m}$ water depth at a mid-lake position (Fig. 2) was installed in November 2006, after which it was emptied and redeployed at about monthly intervals (Table S1). The collected material was allowed to settle for $2 \mathrm{~d}$ and stored frozen after decantation of excess water. Prior to analysis, the samples were thawed, filtered over preweighed and pre-combusted $\left(400^{\circ} \mathrm{C}, 5 \mathrm{~h}\right)$ glass fibre $\mathrm{GF} / \mathrm{F}$ filters (110 mm diameter, Whatman), and then frozen and freeze-dried. Bulk mass flux was calculated for each month by using the dry weight of the collected particles, the number of days covered, and the surface area of the sediment trap $\left(58 \mathrm{~cm}^{2}\right)$ and is expressed as $\mathrm{mg} \mathrm{m}^{-2} \mathrm{~d}^{-1}$. This study focuses on the brGDGTs in settling particles representing the period from September 2010 to January 2015 ( $n=53$; Table S2). 


\subsubsection{Soil sampling}

Seven soil samples from the collection obtained by Buckles et al. (2014) were selected for brGDGT analysis based on site dissimilarity, i.e. from different origins (lakeshore forest, crater rim, savanna hinterland, small ravine; see Table S3), as described in the original study.

\subsubsection{Lake sediment sampling}

Intact surficial lake-bottom sediment $(2-5 \mathrm{~cm}$ depth) from three sites (CH10-06G: $3^{\circ} 19.049^{\prime} \mathrm{S}, 37^{\circ} 41.879^{\prime} \mathrm{E}$; CH1009G: $3^{\circ} 18.704^{\prime} \mathrm{S}, 37^{\circ} 41.448^{\prime} \mathrm{E}$ and CH10-10G: $3^{\circ} 18.575^{\prime} \mathrm{S}$, $37^{\circ} 41.419^{\prime} \mathrm{E}$; see Table S4) forming a transect from close to the creek inlet towards the middle of the lake (Buckles et al., 2014) was collected by gravity coring in JanuaryFebruary 2010, and then freeze-dried and homogenized prior to extraction.

\subsection{Sample preparation and lipid extraction}

Sample preparation for SPM was described in detail by van Bree et al. (2018). For this study, SPM was used from all depths for the months of November 2013 and August 2014, as well as from $0,10,25,35,50,60,70$ and $80 \mathrm{~m}$ depth for all other months (total $n=146$ ). In short, the freeze-dried filters were cut in small pieces and extracted using a modified Bligh-Dyer method. Each extract was acid-hydrolyzed with $1.5 \mathrm{~N} \mathrm{HCl}$ in methanol $(\mathrm{MeOH})$. After a $2 \mathrm{~h}$ reflux at $80^{\circ} \mathrm{C}$, the $\mathrm{pH}$ of the hydrolyzed extract was adjusted to 45 by addition of $1 \mathrm{~N} \mathrm{KOH} / \mathrm{MeOH}(96 \%)$, and washed three times with dichloromethane (DCM). The combined organic phases were passed over a $\mathrm{Na}_{2} \mathrm{SO}_{4}$ column and dried under $\mathrm{N}_{2}$. The total lipid extract (TLE) obtained was separated on an activated $\mathrm{Al}_{2} \mathrm{O}_{3}$ column into apolar, neutral and polar fractions, using, respectively, hexane: DCM $(9: 1, v / v)$, $\mathrm{DCM}$ and DCM : MeOH $(1: 1, v / v)$ as eluents. The freezedried filters with sediment-trap material were cut into small pieces and extracted directly by acid hydrolysis. The obtained TLE was further processed in similar manner as the SPM TLE. The lake-sediment samples were also extracted and processed in a similar way to the SPM.

A known amount of internal standard ( $99 \mathrm{ng} \mathrm{C}_{46}$ GDGT; Huguet et al., 2006) was added to the polar fraction of SPM, settling particles and sediments. All polar fractions of SPM, sediment trap, surface sediments and soils were re-dissolved in hexane:isopropanol $(99: 1, v / v)$, and then passed over a $0.45 \mu \mathrm{m}$ PTFE filter.

\subsection{GDGT analysis and proxy calculation}

GDGT analysis was performed with an Agilent 1260 Infinity ultra-high-performance liquid chromatography (UHPLC) coupled to an Agilent 6130 single quadrupole mass detector, either at Utrecht University (most SPM, soil, surface sediments) or at the NIOZ (settling particles, SPM at $0 \mathrm{~m}$, except November 2013 and September 2014). The instruments at both laboratories are tuned towards the same standards and follow the method of Hopmans et al. (2016), in which separation is achieved by two silica Waters Acquity UPLC HEB Hilic $(\varnothing 1.7 \mu \mathrm{m})$ columns at $30^{\circ} \mathrm{C}$, preceded by a guard column with similar packing. Isocratic elution was used for GDGT separation, starting with $82 \%$ A (hexane) and $18 \% \mathrm{~B}$ (hexane : isopropanol, 9:1) for $25 \mathrm{~min}$ at a flow rate of $0.2 \mathrm{~mL} \mathrm{~min}^{-1}$, followed by a linear gradient to $70 \% \mathrm{~A}$ and $30 \% \mathrm{~B}$ for $25 \mathrm{~min}$. Injection volume was $10 \mu \mathrm{L}$ for settling particles, sediment and soils, and $20 \mu \mathrm{L}$ for SPM. Ionization of the GDGTs was achieved by atmospheric pressure chemical ionization with gas temperature of $200^{\circ} \mathrm{C}$, vaporizer temperature of $400^{\circ} \mathrm{C}, \mathrm{N}_{2}$ flow of $6 \mathrm{~L} \mathrm{~min}^{-1}$, capillary voltage of $3500 \mathrm{~V}$, nebulizer pressure of $25 \mathrm{psi}$ and corona current of $5.0 \mu \mathrm{A}$ as source conditions.

GDGTs were identified by detecting the $[\mathrm{M}+\mathrm{H}]^{+}$ions in selected ion monitoring (SIM) mode for $\mathrm{m} / \mathrm{z}$ 1018, 1020, 1022, 1032, 1034, 1036, 1046, 1048, 1050 (brGDGTs) and 744 (internal $\mathrm{C}_{46}$ GDGT standard). Peak area integration of the GDGTs was done with Chemstation (SPM, soil, sediment) or Agilent Masshunter (settling particles, SPM at 0, 35,60 and $70 \mathrm{~m}$ ) software. For quantification, areas were compared to that of the internal standard, assuming a comparable response of the mass spectrometer for all GDGTs. Fractional abundances of brGDGTs were calculated by dividing the peak area of a specific brGDGT divided by the peak areas of all measured brGDGTs.

The Roman numerals in the following equations refer to the molecular structures of GDGTs as shown in Fig. 1, with 6-methyl brGDGTs distinguished by an accent, and square brackets indicating the fractional abundances of the 15 different brGDGTs. The Cyclization of Branched Tetraethers $\left(\mathrm{CBT}^{\prime}\right)$ was defined by De Jonge et al. (2014b) as

$$
\begin{aligned}
\mathrm{CBT}^{\prime} & =-\log \left\{\left([\mathrm{Ic}]+\left[\mathrm{IIa}^{\prime}\right]+\left[\mathrm{IIb}^{\prime}\right]+\left[\mathrm{IIc}^{\prime}\right]+\left[\mathrm{IIIa}^{\prime}\right]\right.\right. \\
& \left.\left.+\left[\mathrm{IIIb}^{\prime}\right]+\left[\mathrm{IIIc}^{\prime}\right]\right) /([\mathrm{Ia}]+[\mathrm{III}]+[\mathrm{IIII}])\right\},
\end{aligned}
$$

where $[x]$ refers to the fractional abundance of a specific brGDGT.

The isomerization ratio of the 6-methyl penta- and hexamethylated brGDGTs over 5-methyl and 6-methyl brGDGTs (IR $6 \mathrm{ME}$ ) was modified from De Jonge et al. (2014b) and Sinninghe Damsté (2016) and calculated as

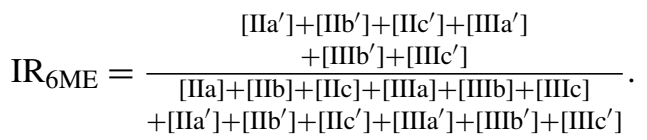

Mean annual air temperature (MAAT) was reconstructed with the stepwise forward selection (SFS) calibration of the brGDGT distribution in the East African lakes dataset (Russell et al., 2018):

$$
\begin{aligned}
\text { MAAT }_{\mathrm{SFS}} & =23.81-31.02 \cdot[\mathrm{IIIa}]-41.91 \cdot[\mathrm{IIb}] \\
& -51.59 \cdot\left[\mathrm{IIb}^{\prime}\right]-24.70 \cdot[\mathrm{IIa}]+68.80 \cdot[\mathrm{Ib}] .
\end{aligned}
$$


Surface water $\mathrm{pH}$ was reconstructed with the Russell et al. (2018) transfer function determined for East African lakes:

Surface water $\mathrm{pH}=8.95+2.65 \cdot \mathrm{CBT}^{\prime}$.

\subsection{Determination of 16S rRNA gene diversity and abundance}

DNA was extracted from a $1 / 32$ section of the SPM filters using the PowerSoil DNA extraction kit (Mo Bio Laboratories, Carlsbad, CA, USA). The $16 \mathrm{~S}$ rRNA gene amplicon sequencing and analysis was performed with the general 16S rRNA archaeal and bacterial primer pair $515 \mathrm{~F}$ and 806RB targeting the V4 region (Caporaso et al., 2012), as described in Besseling et al. (2018). PCR products were gel-purified using the QIAquick Gel-Purification kit (Qiagen), pooled and diluted. Sequencing was performed at the Utrecht Sequencing Facility (Utrecht, the Netherlands) using an Illumina MiSeq $2 \times 300 \mathrm{bp}$ sequencing platform. The 16S rRNA gene amplicon sequences were analysed by an in-house pipeline including quality assessment by FastQC (Andrews, 2010), assembly of the paired-end reads with PEAR (Zhang et al., 2013) and taxonomic assignment (including picking of a representative set of sequences with the "longest" method; Caporaso et al., 2010) with BLAST (Altschul et al., 1990) by using the Silva 128 release as reference database (https://www.arb-silva.de/, last access: January 2019). The $16 \mathrm{~S}$ rRNA gene copies were quantified using quantitative PCR (qPCR) with the same primer pair (515F, 806RB) as was used for amplicon sequencing. The $25 \mu \mathrm{L}$ qPCR reaction mixture contained $1 \mathrm{U}$ of Pico Maxx highfidelity DNA polymerase (Stratagene, Agilent Technologies, Santa Clara, CA), $2.5 \mu \mathrm{L}$ of $10 \times$ Pico Maxx PCR buffer, $2.5 \mu \mathrm{L}$ of each dNTP at a concentration of $2.5 \mathrm{mM}, 0.5 \mu \mathrm{L}$ BSA at a concentration of $20 \mathrm{mg} \mathrm{mL}^{-1}, 0.02 \mathrm{pmol} \mu \mathrm{L}^{-1}$ of primers, Invitrogen SYBR Green ${ }^{\circledR}$ (optimized concentration) diluted 10000 times, $0.5 \mu \mathrm{L}$ of $50 \mathrm{mM} \mathrm{MgCl}_{2}$, and ultrapure sterile water. The cycling conditions for the qPCR reaction were the following: initial denaturation at $98^{\circ} \mathrm{C}$ for $30 \mathrm{~s}, 45$ cycles at $98^{\circ} \mathrm{C}$ of $10 \mathrm{~s}$ each, pausing at $56^{\circ} \mathrm{C}$ for $20 \mathrm{~s}$, followed by a plate read, at $72^{\circ} \mathrm{C}$ for $30 \mathrm{~s}$, and finally at $80^{\circ} \mathrm{C}$ for $25 \mathrm{~s}$. Specificity of the reaction was tested with a gradient melting-temperature assay, from 55 to $95^{\circ} \mathrm{C}$ with a $0.5^{\circ} \mathrm{C}$ increment for $5 \mathrm{~s}$. The qPCR reactions were performed in triplicate with standard curves from 100 to 107 molec. $\mu \mathrm{L}^{-1}$. The qPCR efficiency for the 16S rRNA quantification was on average $95 \%$ with $R^{2}=0.998$.

\subsection{Statistical analysis}

To assess variability in brGDGT distribution among (types of) samples we performed principal component analysis (PCA) in the R-package FactoMineR (Lê et al., 2008). For SPM, statistic analysis only used the fractional abundance of the most abundant brGDGTs, i.e. Ia, Ib, IIa, IIa' $\mathrm{IIb}^{\prime} \mathrm{IIb}^{\prime}$, IIIa and IIIa'. Water temperature and $\mathrm{pH}$ were also included in the
PCA, with pH between 50 and $90 \mathrm{~m}$ water depth assumed to be similar to the $\mathrm{pH}$ measured at $50 \mathrm{~m}$ depth. Although complete $\mathrm{pH}$ profiles from Lake Chala show that $\mathrm{pH}$ still decreases slightly with depth below $50 \mathrm{~m}(\sim 0.5 \mathrm{pH}$ units; Wolff et al., 2014), this represents only a quarter of the total $\mathrm{pH}$ depth gradient.

Concentrations of brGDGTs $\left(\mathrm{ng} \mathrm{L}^{-1}\right)$ were correlated with the estimated abundance of microbial groups to assign a possible source of the former. The abundance of specific bacterial groups was estimated by multiplying their relative abundance as obtained by 16S rRNA gene amplicon sequencing analysis with the absolute abundance of microorganisms in a given sample based on qPCR. For simplicity it was assumed that each microbe contains a single 16S rRNA copy in their genome; the abundance was accordingly expressed as $16 \mathrm{~S}$ rRNA gene copies $\mathrm{L}^{-1}$. On the premise that potential brGDGT producers must be frequently present in the water column, microbial species present in less than $10 \%$ of the SPM samples were excluded from this comparison.

\section{Results}

\subsection{Seasonal mixing and stratification}

Surface water temperature as measured by temperature loggers at $2 \mathrm{~m}$ depth over the 29-month period from September 2012 to January 2015 , ranged between $22.8^{\circ} \mathrm{C}$ during the mixing season in August 2013 and $27.6^{\circ} \mathrm{C}$ during the period of strong stratification in April 2013 (Fig. 3). Temperatures at 10,20 and $25 \mathrm{~m}$ depth, i.e. in lower epilimnetic and upper hypolimnetic water, varied seasonally with minima during the period of shallow mixing (SM; January-February) and towards the end of the period of deep mixing (DM; May to mid-September). Seasonal temperature variation at $50 \mathrm{~m}$ depth, i.e. near the mixing limit, was already strongly muted, and at $85 \mathrm{~m}$ depth water temperature remained stable at $\sim 22.4^{\circ} \mathrm{C}$ (Fig. 3), indicating lack of mixing. Over the 4.5-year monitoring period from September 2010 to January 2015 the upper water column of Lake Chala also developed stratification generally from September until April, with the most strongly stratified conditions (i.e. greatest temperature contrast between the surface and deep water) shortly after the annual peak in local air temperature (FebruaryMarch; Fig. 3).

During the 17-month period of lake monitoring between September 2013 and January 2015, the thickness of oxygenated upper part of the water column, as based on the depth to anoxia (shallowest depth with $<0.2 \mathrm{mg} \mathrm{L}^{-1}$ dissolved oxygen), varied between $17 \mathrm{~m}$ in October-November 2013 and $44 \mathrm{~m}$ in October-November 2014 (Fig. 3). Depression of the oxycline resulted from convection-driven oxygen injection, mainly towards the end of the stratified period and throughout the principal mixing period. In contrast, the pe- 


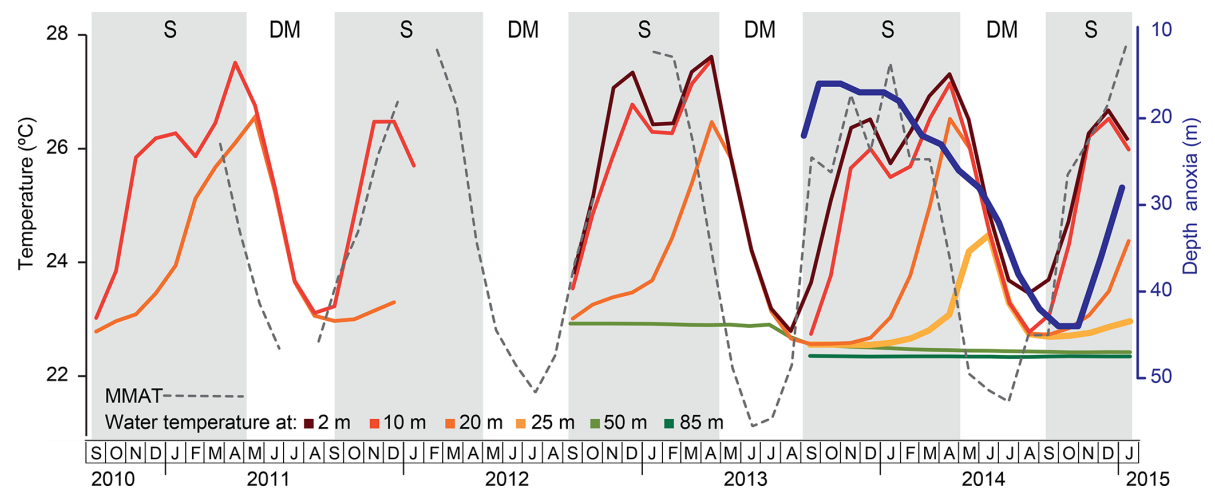

Figure 3. Temperature $\left({ }^{\circ} \mathrm{C}\right)$ variation within the water column of Lake Chala between September 2010 and January 2015, based on automatic loggers suspended at 2, 10, 20, 25, 50 and $80 \mathrm{~m}$ depth (as available), in relation to the Bodé et al. (2020) time series of mean monthly air temperature (MMAT; stippled line) at a savanna site $\sim 25 \mathrm{~km}$ west of Lake Chala. The dark blue line shows the position of the oxycline between September 2013 and December 2015, based on the shallowest depth with dissolved oxygen concentration $<0.2 \mathrm{mg} \mathrm{L}{ }^{-1}$, as measured by monthly water column profiling (van Bree et al., 2018). Grey shading highlights the seasonal periods of upper water column stratification (S) and deep mixing (DM). Due to the hiatus in temperature logging data, timing of the start and end of the deep-mixing period in 2012 was inferred from the MMAT trend.

riod of shallow mixing in January-February had little impact on the depth of the oxycline (Fig. 3).

\subsection{Spatial and temporal distribution of brGDGTs in SPM}

BrGDGTs were detected in all SPM samples analysed $(n=$ 143, Fig. 4). However, the abundance of brGDGTs with one or two cyclopentyl moieties (types b and c; Fig. 1) was often too low for reliable quantification (i.e. peak height less than three times the noise level of the baseline). Specifically, concentrations of brGDGTs IIIc and IIIc' were always below detection limit, and brGDGTs Ic, IIc, IIc', IIIb and III'b were present in less than half of the SPM samples and in very modest amounts, often around the detection limit. The IIIa" isomer (Weber et al., 2015), which has so far been detected only in lakes, was not detected at all in our samples. Consequently, in the following analysis we focus on the eight brGDGTs that were detected in at least $60 \%$ of the samples (i.e. Ia, Ib, IIa, IIa', IIb, II' ${ }^{\prime}$, IIIa and $\mathrm{IIIa}^{\prime}$ ) unless stated otherwise.

The total concentration of these eight brGDGTs in the water column ( $\Sigma$ brGDGTs) varied between 0.2 and $24 \mathrm{ng} \mathrm{L}^{-1}$ $(n=143)$ and generally increased with depth, especially in the anoxic part of the water column (Fig. 4). The concentration-weighted mean fractional abundances of the individual brGDGTs in SPM collected at all depths above the sediment trap (0-35 m; $\left.\mathrm{SPM}_{\text {abovetrap }}\right)$ and below it (40$90 \mathrm{~m}$; $\left.\mathrm{SPM}_{\text {belowtrap }}\right)$ over the 17-month sampling period are shown in Fig. 5a. Pentamethylated (type II) brGDGTs were the most common overall, with a summed fractional abundance ranging from 0.44 to 0.74 in the total dataset $(n=$ 143) and average values of 0.64 in $\operatorname{SPM}_{\text {abovetrap }}(n=72)$ and 0.72 in SPM $_{\text {belowtrap }}(n=71)$. BrGDGT IIa' was of- ten dominant in the SPM of Lake Chala, with a fractional abundance ranging from 0.11 to 0.60 and average values for

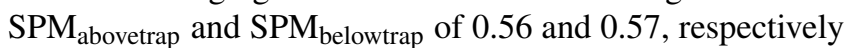
(Fig. 5a). The tetramethylated (type I) brGDGTs amount to between 0.06 and 0.47 of the brGDGT fractional abundance $(n=143)$, with average values of 0.31 in $\left.\mathrm{SPM}_{\text {abovetrap }}\right)$ and 0.21 in $\mathrm{SPM}_{\text {belowtrap}}$; brGDGT Ia is the second-most abundant of all brGDGTs (Fig. 5a). Finally, the concentration of hexamethylated (type III) brGDGTs is relatively variable with a combined fractional abundance between 0 and $0.25(n=143)$, where brGDGT IIIa' is the most dominant compound. The hexamethylated brGDGTs have relatively low concentration-weighted average fractional abundances of 0.05 in $\mathrm{SPM}_{\text {abovetrap }}$ and 0.08 in $\mathrm{SPM}_{\text {belowtrap. }}$ Overall the tetramethylated brGDGTs are relatively more common in the upper water column (fractional abundances $\mathrm{SPM}_{\text {abovetrap }}>\mathrm{SPM} \mathrm{M}_{\text {belowtrap}}$ ), whereas penta- and hexamethylated brGDGTs are relatively more abundant in the lower water column ( $\left.\mathrm{SPM}_{\text {abovetrap }}<\mathrm{SPM}_{\text {belowtrap }}\right)$.

In $>86 \%$ of all SPM samples, 6-methyl brGDGTs were more abundant than 5-methyl brGDGTs, which is reflected in an average $\mathrm{IR}_{6 \mathrm{ME}}$ of 0.74 (range $0.38-1.00$ ). The 5methyl brGDGTs were relatively abundant only between November 2013 and August 2014, with a maximal fractional abundance of 0.33 at $35 \mathrm{~m}$ in February 2014. Absolute concentrations of 5-methyl brGDGTs peaked at $8.0 \mathrm{ng} \mathrm{L}^{-1}$ at $60 \mathrm{~m}$ depth in April 2014. This is mainly the result of brGDGT-IIb, which contributed $4.8 \mathrm{ng} \mathrm{L}^{-1}$ to this amount (Fig. 4). The concentration of 6-methyl brGDGTs was typically highest in the non-mixing deepest part of the water column $(>60 \mathrm{~m})$ and reaches $9.3 \mathrm{ng} \mathrm{L}^{-1}$ at $80 \mathrm{~m}$ in February 2014 (Fig. 4). However, averaged over the sampling period, the concentration-weighted fractional abundance of 6methyl brGDGTs was quite similar in shallow and deep wa- 

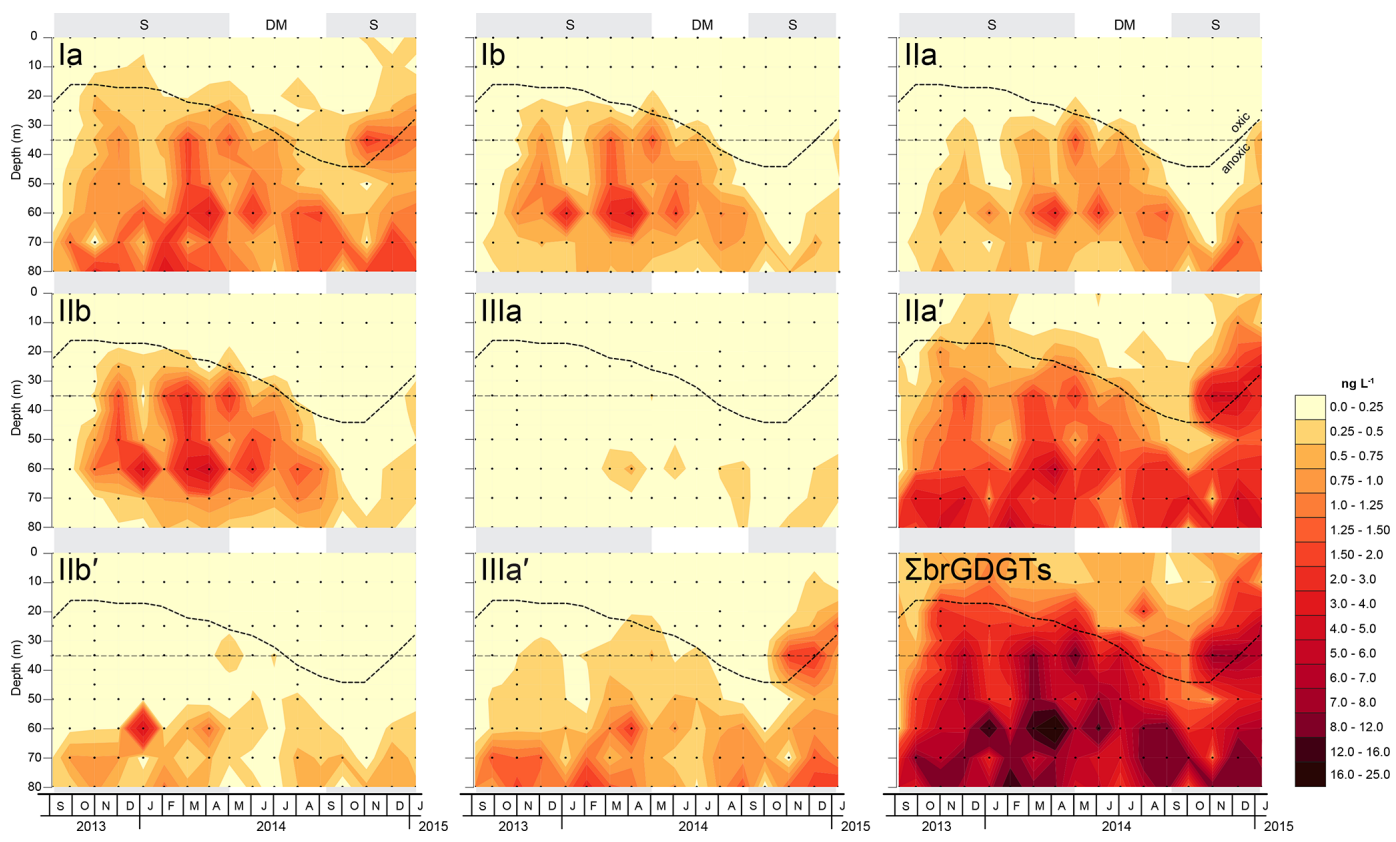

Figure 4. Depth-interpolated concentrations (in $\mathrm{n} \mathrm{L} \mathrm{L}^{-1}$ ) of the summed and eight most common individual brGDGT compounds in SPM collected at eight depth intervals (occasionally 13) between 0 and $80 \mathrm{~m}$ in Lake Chala, at approximately monthly intervals between September 2013 and January 2015. Also indicated is the varying position of the oxycline (bold stippled line) in relation to the static position of the sediment trap at $35 \mathrm{~m}$ depth (thin dashed line), which separates the $\mathrm{SPM}_{\text {abovetrap }}$ and $\mathrm{SPM}_{\text {belowtrap }}$ zones. Grey background shading indicates the seasonal periods of upper water column stratification (S) and deep mixing (DM), as in Fig. 3.

ter, with an $\mathrm{SPM}_{\text {abovetrap }}$ value of 0.62 and $\mathrm{SPM}_{\text {belowtrap value }}$ of 0.66 .

The concentrations of both $\Sigma$ brGDGT and individual brGDGTs were highest in the anoxic part of the Chala water column under stratified conditions (Fig. 4). Importantly, depth-integrated concentrations (i.e. averaged over the entire water column) were also highest during the stratification periods and lowest towards the end of the deep-mixing period in 2014 when the oxycline was maximally depressed. Towards the end of both 2013 and 2014, brGDGT concentrations increased when stratification developed after the period of deep mixing. However, the two stratification periods differed with regard to the fractional abundance of individual brGDGTs. During stratification in 2013/2014, the brGDGT assemblage mainly consisted of Ib and IIb at 35-60 m water depth, and IIa $^{\prime}$ and IIIa $^{\prime}$ at $60-80 \mathrm{~m}$, whereas during stratification in late 2014 and early 2015, concentrations of Ib and IIb were strongly reduced and notably high concentrations of $\mathrm{IIa}^{\prime}$ and IIIa' ${ }^{\prime}$ were evident up to $25-35 \mathrm{~m}$ water depth (Fig. 4).

The first three principal components (PCs) of a principal component analysis (PCA) on the fractional abundances of the eight major brGDGTs in all SPM samples $(n=143)$ together explain $83.5 \%$ of the observed variation in their distribution (Fig. 6a-b). PC1 explains $49.4 \%$ of the variance; has strong negative loadings for the 6-methyl brGDGTs IIa' and IIIa'; $^{\prime}$ and has strong positive loadings for the 5-methyl brGDGTs Ib, IIa, IIb, and IIIa. PC2 explains $21.0 \%$ of the variance and mainly shows strong negative loadings for Ia and $\mathrm{IIb}^{\prime}$. PC3 explains $13.1 \%$ of the variance and shows a strong positive loading for IIb' and IIIa.

\subsection{BrGDGTs in settling particles}

The total brGDGT flux captured by the sediment trap at $35 \mathrm{~m}$ depth varied by 2 orders of magnitude (between 84 and $5300 \mathrm{ng} \mathrm{m}^{-2} \mathrm{~d}^{-1}$ ) over the 53 -month period of sedimenttrap deployment (Fig. 7b). Total brGDGT flux is not related $\left(R^{2}=0.02, p=0.91\right)$ to the bulk flux of settling particles (Fig. 7a), nor does its production (or sedimentation) appear to be concentrated in a specific season. BrGDGT concentrations in the monthly collection of settled particles were generally higher than in the snapshot SPM samples, enabling quantification of all studied brGDGTs except IIIc. Nevertheless, like in SPM, the fractional abundance of brGDGTs IIc, IIIb and IIIc' was $<0.02$ at all times, and rarely $>0.02$ for Ic, IIc', IIIa and IIIb' (Fig. 5a). BrGDGTs IIc, IIIb and IIIc' were also found in only $62 \%-77 \%$ of the 53 trap samples, whereas all other brGDGTs were found in at least $94 \%$ of these samples.

The distribution of brGDGTs shows large variation throughout the period of settling particle collection (Fig. 7bf). The majority of brGDGTs in settling particles were pentamethylated, with a combined fractional abundance ranging between 0.46 and $0.61(n=53)$, similar to what was found for SPM. BrGDGT IIa' was again most often the dom- 


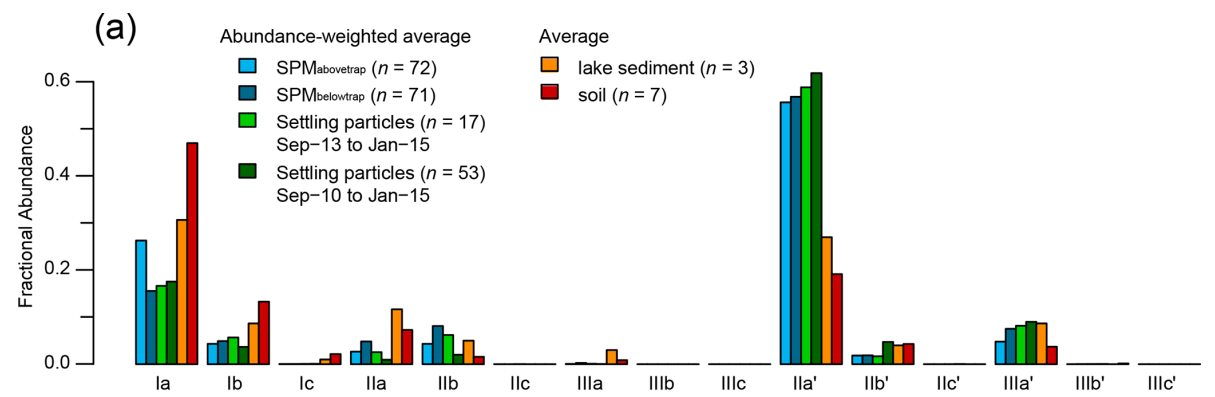

(b)

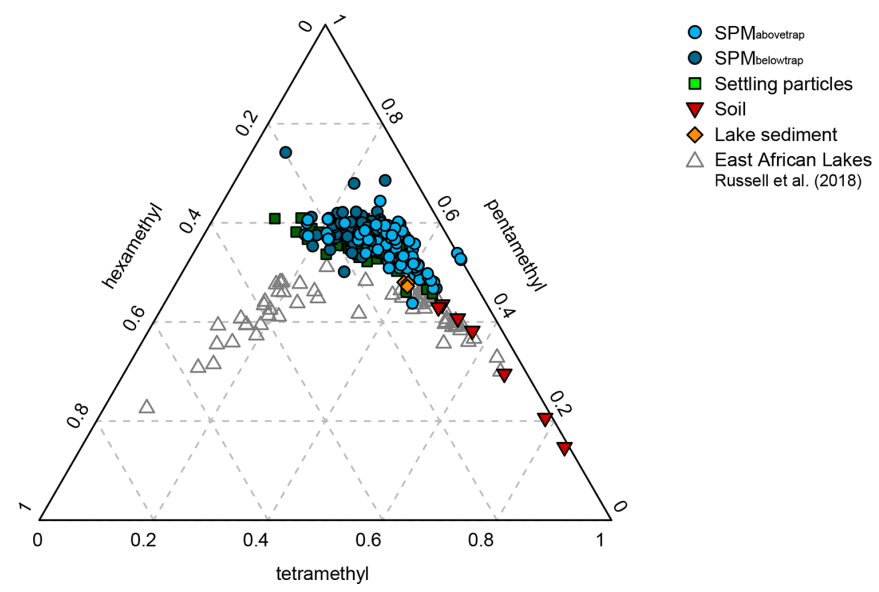

Figure 5. Average distribution of brGDGTs in the various sets of samples analysed in this study. (a) Temporally integrated, concentrationor flux-weighted average fractional abundances of individual brGDGT compounds in SPM from above (light blue) and below (dark blue) the sediment trap, and settling particles trapped over the 17-month period of SPM sampling (September 2013 to January 2015; light green) and over the longer 53-month period starting 3 years earlier (September 2010 to January 2015, dark green), compared with average fractional abundances of the same brGDGTs in surficial lake-bottom sediments (orange) and catchment soils (red). (b) Proportion of tetra-, penta- and hexamethyl brGDGTs in SPM from above (light blue circles) and below (dark blue circles) the sediment trap and in settling particles (green squares), lake sediments (orange diamonds), and soils (red triangles) plotted over corresponding data from the surficial bottom sediments of 65 East African Lakes (grey triangles; Russell et al., 2018).

inant compound (fluxes of up to $3200 \mathrm{ng} \mathrm{m}^{-2} \mathrm{~d}^{-1}$ in November 2014; Fig. 5a), although at times IIb (340 $\mathrm{ng} \mathrm{m}^{-2} \mathrm{~d}^{-1}$ in March 2014) and $\mathrm{IIb}^{\prime}\left(530 \mathrm{ng} \mathrm{m}^{-2} \mathrm{~d}^{-1}\right.$ in August 2013) were also abundant in the settling particle flux. The fractional abundance of tetramethylated brGDGTs (mostly Ia, as in the SPM) ranged from 0.11 to 0.46 , and hexamethylated brGDGTs (mostly $\mathrm{IIIa}^{\prime}$, as in the SPM) ranged from 0.07 to 0.28 . Further, 6 -methyl brGDGTs most often (41 out of 53 months) comprised at least $80 \%$ of the total 5- and 6-methyl brGDGTs (IR $6 \mathrm{ME}>0.8$ ), except in June 2011 and from November 2013 to September 2014 (Fig. 7c).

The first three PCs of the PCA on the fractional abundances of the eight brGDGTs most common in settling particles (Ia, Ib, IIa, IIa', IIb, IIb', IIIa and IIIa', i.e. as in the SPM) together explain $91.4 \%$ of the observed variation through time ( $n=53$; Fig. $6 \mathrm{c}-\mathrm{d}$ ). PC1 explains $57.5 \%$ of the variance and has strong negative loadings for the 6methyl brGDGTs IIa' and $\mathrm{IIIa}^{\prime}$, and positive loadings for the 5-methyl brGDGTs Ia, Ib, IIa, IIb and IIIa. PC2 explains $23.7 \%$ of the total variance and has strong negative loadings for Ia and $\mathrm{IIb}^{\prime}$, and positive loadings for especially IIa, IIb and IIIa. PC3 explains $10.2 \%$ of the total variance and has a strong positive loading for Ia. Thus, variation in individual brGDGT distributions is overall similar in SPM and settling particles (cf. Fig. 6a-b and c-d).

The combined PCA on all 143 SPM and 53 sediment-trap samples (Fig. 6e) indicates that variation in brGDGT distributions is mainly structured by the relative abundance of 5and 6-methyl brGDGTs (PC1 explains $48.6 \%$ of the total variance), and by a different behaviour of brGDGTs Ia and $\mathrm{IIb}^{\prime}$ from the six other brGDGTs (PC2 explains $22.4 \%$ of the total variance). As expected, the brGDGT distribution in settling particles is most similar to that in SPM from the upper water column, i.e. sampled at depths situated above the sediment trap (Fig. 6e).

\subsection{BrGDGTs in catchment soils}

BrGDGTs in soils surrounding Lake Chala $(n=7)$ are predominantly tetramethylated (fractional abundance 0.48 

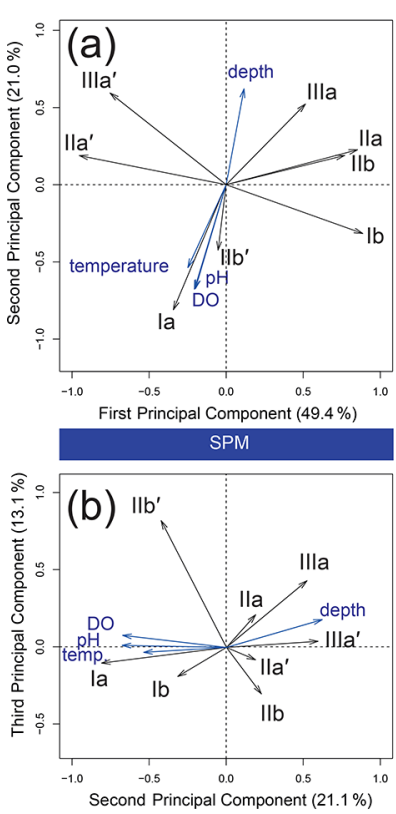
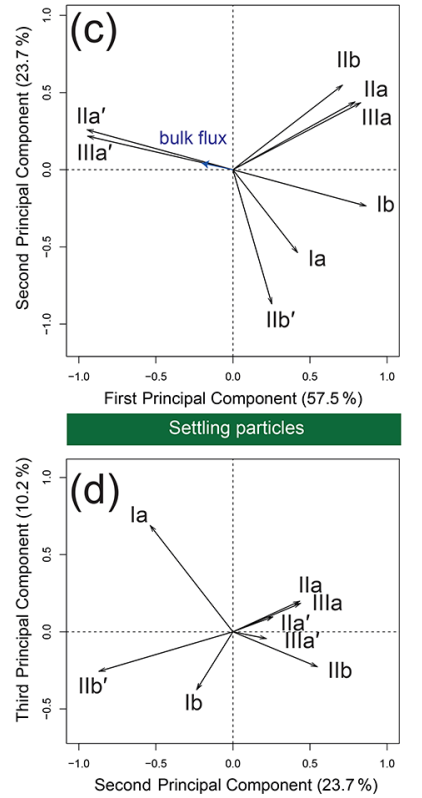

(e)

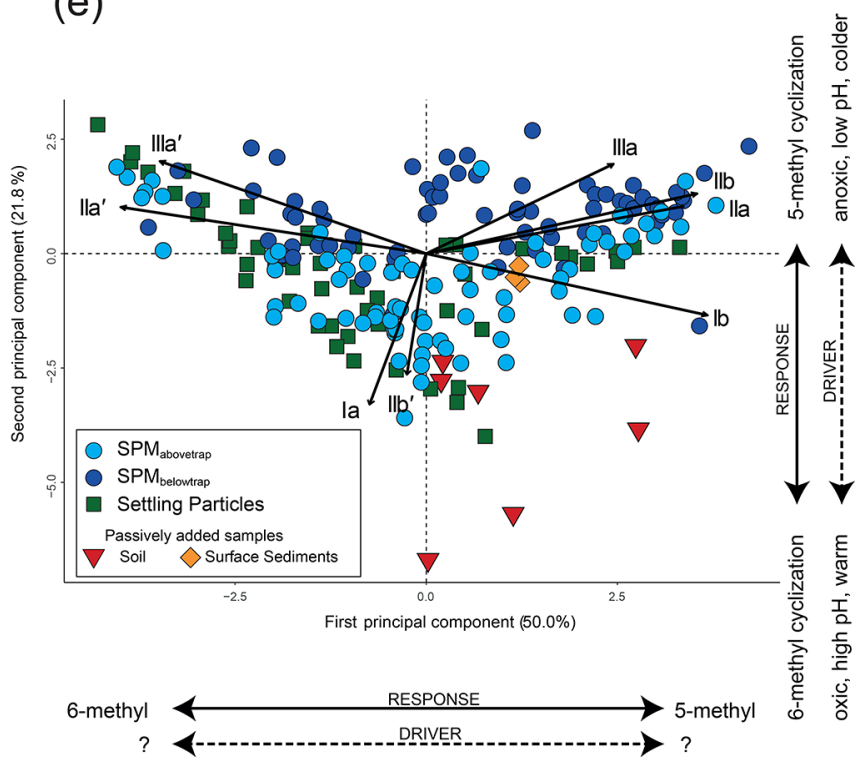

Figure 6. Principal component analysis (PCA) of the fractional abundances of the eight major brGDGTs in SPM ( $n=143$ ) and settling particles $(n=53)$ from Lake Chala. (a-b) PC1 vs. PC2 (a) and PC2 vs. PC3 (b) of the SPM samples, with black vectors indicating the PCA scores of individual brGDGTs, and blue vectors showing the PCA scores of environmental variables added passively. Temperature and $\mathrm{pH}$ are measured (0-50 m depth, van Bree et al., 2018) and assumed constant from 50 to $80 \mathrm{~m}$ depth. (c-d) PC1 vs. PC2 (c) and PC2 vs. PC3 (d) of the settling particles, with black vectors indicating the PCA scores of individual brGDGTs, and the blue vector showing the PCA score of the total bulk settling flux added passively. (e) Combined PCA of the fractional abundances of the (mainly aquatic) brGDGTs in all SPM (blue circles) and settling-particle (green squares) samples, with distinction between SPM from above (light blue) and below (dark blue) the sediment trap. The PCA scores of lake sediments (orange diamonds) and soils (red triangles) were added passively.

$0.84)$, followed by pentamethylated $(0.15-0.44)$ and hexamethylated (0.01-0.09) compounds (Fig. 5b). Tetramethylated brGDGTs and compounds $\mathrm{IIa}^{\prime}, \mathrm{IIb}^{\prime}$, and $\mathrm{IIIa}^{\prime}$ were present in all analysed soils. Several penta- and hexamethylated brGDGTs were below detection limit in two (IIa, IIIb), three (IIb), four ( $\left.\mathrm{IIa}^{\prime}, \mathrm{IIIb}^{\prime}\right)$, five (IIIa) or all seven (IIIc, IIIc') soil samples, and the fractional abundance of IIc, IIc' ${ }^{\prime}$, IIIb and $\mathrm{IIIb}^{\prime}$ was usually $<0.02$ (Fig. 5a). The IR6ME of Chala soils ranges between 0.52 and 0.90 , with an average value of 0.73 (Fig. 7c). Variation in brGDGT distributions among soils is explained mainly by their location inside or outside of the crater basin (hinterland savanna, ravine, crater rim or lakeshore forest), in line with results of earlier analyses that did not differentiate between 5- and 6-methyl brGDGTs (Buckles et al., 2014). The brGDGT distributions in soils differ substantially from those in SPM and settling particles, mainly because of higher fractional abundances of brGDGTs Ia, Ib and IIa, and correspondingly lower proportions of 6methyl brGDGTs (Fig. 5a). When soil brGDGT distributions are added to the PCA of water column brGDGTs as passive samples, all soils plot in the third quadrant of positive PC1 and negative PC2 values, distinct from the lake SPM and settling particles (Fig. 6e).

\subsection{BrGDGTs in surficial lake-bottom sediments}

All brGDGTs except IIIc and IIIc ${ }^{\prime}$ were detected in recently deposited lake-bottom sediments $(n=3)$, although the fractional abundances of Ic, IIc, IIc', IIIb and III'b' are always $<0.02$ (Fig. 5a). The distribution of individual brGDGTs is very similar among the three analysed samples (Figs. $5 \mathrm{~b}$ and 6e), with fractional abundances of $0.47-0.48$ for penta-, $0.40-0.41$ for tetra-, and 0.12 for hexamethylated brGDGTs and Ia (0.31) and $\mathrm{IIa}^{\prime}(0.27)$ being the dominant compounds. $\mathrm{IR}_{6 \mathrm{ME}}$ is $\sim 0.67$ (Fig. 7c). The brGDGT distribution in these lake sediments falls within the range of those found in SPM and settling particles (Fig. 5 b) but with only positive PC1 scores (Fig. 6e).

\subsection{Microbial diversity and abundance in the water column of Lake Chala}

The diversity and abundance of prokaryotes in the water column of Lake Chala was determined by analysis of all collected SPM samples $(n=216)$, using Q-PCR and 16S rRNA gene amplicon sequencing. Proteobacteria formed the most important group of microbes but Acidobacteria, Actinobacteria, Chlorobi, Chloroflexi, Cyanobacteria, Firmicutes, Bacteriodetes, Planctomycetes, Parcubacteria, and Verrucomicro- 

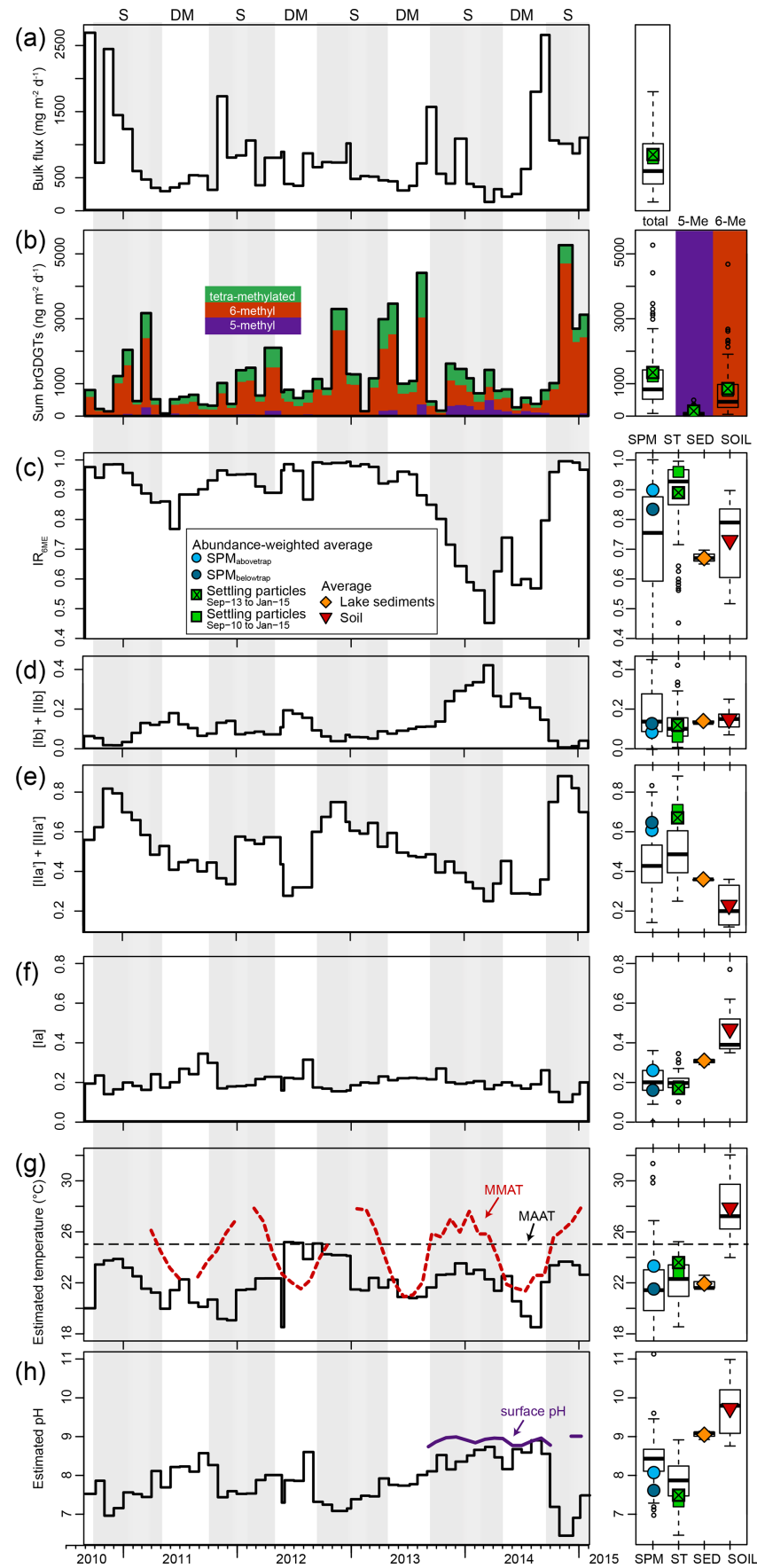

Figure 7. Time series of settling-particle data from Lake Chala, based on 53 months of sediment-trap deployment between August 2010 and January 2015. (a) Temporal variation in total bulk dry flux $\left(\mathrm{mg} \mathrm{m}^{-2} \mathrm{~d}^{-1}\right)$. (b) Total brGDGT flux (ng m $\left.{ }^{-2} \mathrm{~d}^{-1}\right)$ with an indication of the proportions of tetra-methylated (green), 5-methyl (purple) and 6-methyl (brown) brGDGTs. (c) Fraction of 6-methyl penta- and hexamethylated brGDGTs (IR6ME). (d-f) Fractional abundances of brGDGTs Ib + IIb (d), IIa $^{\prime}+\mathrm{IIIa}^{\prime}$ (e) and Ia (f). (g) Reconstructed mean annual air temperature (MAAT), using the East African lakes (EAL) calibration of Russell et al. (2018). Also indicated are MMAT (red dashed line) and MAAT (black dashed line), both from Bodé et al. (2020). (h) Reconstructed surface water pH, using the EAL calibration of Russell et al. (2018), and pH measured at the surface $(0 \mathrm{~m})$ during the period September 2013 to January 2015 (van Bree et al., 2018). The right-hand panels show boxplots indicating median, interquartile, minimum, maximum, and outlier values of the bulk and brGDGT fluxes and proxies (a-b); suspended-particulate data (SPM in $\mathbf{c}-\mathbf{h} ; n=143$ ); settling-particle data (ST in $\mathbf{c}-\mathbf{h} ; n=53)$; lake-sediment data (SED in $\mathbf{c}-\mathbf{h} ; n=3$; and catchment soil data (SOIL in $\mathbf{c}-\mathbf{h} ; n=7$ ). These box plots are superimposed with flux- or abundance-weighted average values of the same for SPM abovetrap (light blue circle), SPM belowtrap (dark blue circle), settling particles trapped over the 17-month period of SPM sampling (September 2013 to January 2015, crossed green square) or over the 53-month period starting three years earlier (September 2010 to January 2015, green square), lake sediments (orange diamond), and soils (red triangle). Grey background shading highlights the seasonal periods of upper water column stratification (S) and deep mixing (DM). 
bia were also present in varying relative amounts. The relative abundance of Acidobacteria reached a maximum of $4 \%$ but on average represented only $0.1 \%$ of the prokaryotic population (Table S5). Among the Acidobacteria, sequences closely affiliated to Blastocatellia (subdivision, SD, 4), as well as those closely related to SD 21 and SD 6, dominated throughout the water column (Table S5).

The absolute concentrations of the eight most common brGDGTs in the Lake Chala SPM are linked to the spatiotemporal distribution of specific bacterial groups based on 16S rRNA gene abundance estimates (Fig. 8). For Acidobacteria, a suspected phylum of brGDGT producers (Sinninghe Damsté et al., 2011a), the highest degree of correlation was found between Acidobacteria SD 21 and brGDGTs $\mathrm{Ib}\left(R^{2}=0.23, p<0.001, n=132\right)$ and $\operatorname{IIb}\left(R^{2}=0.22, p<\right.$ $0.001, n=117$ ). However, most correlations between individual brGDGTs and Acidobacteria SDs are weak $\left(R^{2}<\right.$ 0.15; Fig. 8a). Outside the phylum Acidobacteria, modest positive correlations $\left(R^{2} \geq 0.2\right)$ were found between at least one of the eight major brGDGTs and the 16S rRNA gene abundance of 12 individual bacterial taxa (Fig. 8b). The highest positive correlation was found between brGDGT IIa and an uncultured bacterium of the phylum Aminicenantes $\left(R^{2}=0.40, p<0.001, n=125\right)$.

\section{Discussion}

\subsection{An aquatic origin of brGDGTs in Lake Chala}

BrGDGTs in lakes can originate from both terrestrial and aquatic sources, and hence a mixed signal can be expected. There are several indications that the SPM of Lake Chala primarily contains brGDGTs produced within the water column rather than being washed in with eroding catchment soils. Firstly, at all times in the seasonal cycle, brGDGT concentrations in the SPM show an order-of-magnitude increase with depth (Fig. 4). Based on data from a limited number of SPM profiles, it was previously thought that this pattern mainly originated because of favourable conditions for organic preservation in the anoxic lower water column of Lake Chala (Sinninghe Damsté et al., 2009; Buckles et al., 2014). Such a presumed stable brGDGT reservoir might be formed when slowly sinking organic particles become neutrally buoyant in the cooler hypolimnion and consequently accumulate over time, combined with a lack of processes (such as grazing and aggregation) to remove these particles from the water column (Sinninghe Damsté et al., 2009; Buckles et al., 2014). However, since our data also show significant variation in the distribution of individual brGDGTs between different depth intervals within the anoxic portion of the water column (Fig. 4), the concept of a static hypolimnetic brGDGT reservoir is untenable. Secondly, the depthintegrated total brGDGT concentration in SPM is lower at the end of the mixing season (and start of the ensuing strati- fication) than during peak stratification conditions (Fig. 4), arguing against the notion that upwelling during the mixing season merely disperses deep-water brGDGTs throughout the water column. Thirdly, the distribution and abundance of individual brGDGTs changes not only with depth but also through time (Fig. 4). The changes in the lower water column are especially remarkable given the fact that the maximum mixing depth between September 2013 and January 2015 was limited to $\sim 45 \mathrm{~m}$ (Fig. 3; van Bree et al., 2018). For example, the total brGDGT concentration at $80 \mathrm{~m}$ depth fluctuated between $0.98 \mathrm{ng} \mathrm{L}^{-1}$ (February 2014) and $16 \mathrm{ng} \mathrm{L}^{-1}$ (October 2014), and the different temporal trends of the individual brGDGTs result in variations in the degrees of cyclization, methylation, and 5- or 6-methyl positioning within the brGDGTs. Finally, the contrast between brGDGT distributions in soils and in SPM from either the oxygenated or anoxic parts of the water column (which largely correspond with the zones above and below the sediment trap; Fig. 5a-b), strongly suggests that high deep-water brGDGT concentrations do not result primarily from the accumulation of soil-derived brGDGTs preserved in anoxic conditions, but from in situ production, especially below the oxycline. Our combined evidence indicates that over the studied 17-month interval, (almost) all brGDGTs in the SPM of the water column of Lake Chala have an aquatic source, while terrestrial input is negligible. This result corroborates the findings of Buckles et al. (2014) and is also consistent with the general lack of terrestrial biomarkers, such as long-chain $n$-alkanes, in the SPM of Lake Chala during this same time interval (van Bree et al., 2018).

\subsection{Spatio-temporal variation in brGDGT distributions}

There is large variation in the fractional abundances of brGDGTs in the water column of Lake Chala over time. Under stratified conditions from November 2013 to $\mathrm{Au}$ gust 2014, the expanded anoxic zone is characterized by high fractional abundances of brGDGTs Ib and IIb, which both peak in abundance at $60 \mathrm{~m}$ depth (Fig. 4). Although seemingly similar environmental conditions occurred at the end of 2014, when after the end of seasonal deep mixing the oxycline moved upwards again, the concentrations of $\mathrm{Ib}$ and $\mathrm{IIb}$ do not return to their earlier levels. Instead, concentrations of $\mathrm{IIa}^{\prime}$ and $\mathrm{IIIa}^{\prime}$ rapidly increase at this time. Hence, it appears that deeper mixing promotes either the production of $\mathrm{Ib}+\mathrm{IIb}$ (5-methyl brGDGTs with rings), as observed in late 2013 and early 2014, or of $\mathrm{IIa}^{\prime}+\mathrm{IIIa}^{\prime}$ (6-methyl brGDGTs with no rings but additional methylation), as observed in late 2014. This temporal variation in brGDGT composition is captured by PC1 in the PCA, which clearly separates 5and 6-methyl brGDGTs (PC1 49.4\%; Fig. 6a). Moreover, the associated alternation of brGDGTs with and without cyclopentyl moieties is reflected by PC2 (Fig. 6a-b). Notably, where 5-methyl brGDGTs mostly occur between 35-60 m 

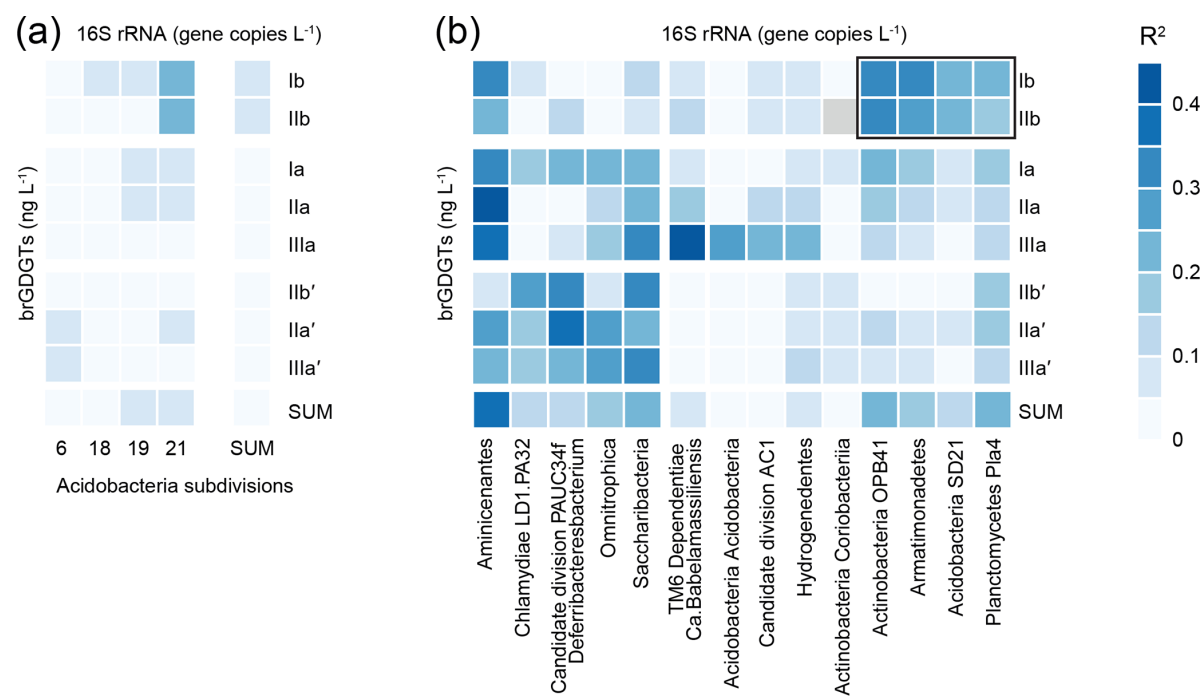

Figure 8. Correlation matrix ( $R^{2}$; represented by shades of blue) between the absolute concentration of the eight major brGDGTs in Lake Chala SPM (ng L ${ }^{-1}$ ) and estimated 16S rRNA gene abundances (copies $\mathrm{L}^{-1}$, see details in text). (a) Acidobacteria SD 6, 18, 19, and 21 and the sum of all Acidobacteria. The Acidobacterial SD operational taxonomic unit (OTUs) are present in at least $10 \%$ of the SPM samples measured for both brGDGTs and gene abundances. Only SDs that correlate with at least one brGDGT with an $R^{2} \geq 0.05$ are shown. (b) The 14 taxa of bacteria displaying highest correlation with individual brGDGTs, divided into clusters of highest correlation with Ib and IIb or with the other brGDGTs. The bacterial OTUs are present in at least $10 \%$ of the SPM samples measured for both biomarkers and gene abundances. Only SDs that correlate with at least one brGDGT with $R^{2} \geq 0.2$ are shown.

depth, 6-methyl brGDGTs generally reside in the lowermost portion of the water column (60-80 m; Fig. 4). The 5- and 6-methyl brGDGTs with cyclopentyl moieties (Ib and IIb vs. $\mathrm{IIb}^{\prime}$ ) also occur in different parts of the water column (Fig. 4). Although the concentrations of $\mathrm{Ilb}^{\prime}$ in SPM are overall quite low, this depth segregation suggests that the incorporation of cyclopentyl moieties into 5-methyl and 6-methyl brGDGTs is driven by different factors.

\subsection{Membrane plasticity vs. community changes in aquatic brGDGT producers}

It is generally assumed that brGDGT producers adjust the molecular structure of their membrane lipids in response to environmental changes, and in fact these membrane adaptations are at the heart of brGDGT-based paleoenvironmental proxies (e.g. Weijers et al., 2007b). In general, the distribution of individual brGDGTs in the SPM of Lake Chala is in line with the ambient environmental conditions. Overall dominance of the 6-methyl brGDGTs (Fig. 5) may be associated with the relatively high $\mathrm{pH}$ of the lake (8.2-9.3 at the surface; Wolff et al., 2014), given that 6-methyl brGDGTs are predominantly produced under high-pH conditions in soils (De Jonge et al., 2014a) and river (De Jonge et al., 2014b) and lake (Russell et al., 2018) water. Also the relatively low abundance of hexamethylated (both 5- and 6methyl) brGDGTs is characteristic for warm lakes (Tierney et al., 2010; Loomis et al., 2014a; Russell et al., 2018). However, in Lake Chala there is no straightforward link between
brGDGT distributions and the seasonal cycle of environmental conditions, as illustrated by the distinct brGDGT distributions in the two episodes of strong stratification during our 17-month study period, and by the apparently different drivers of cyclization in 5-methyl vs. 6-methyl brGDGTs (see Sect. 4.2). The fact that temporal variation in the fractional abundance of aquatically produced brGDGTs is not easily linked to the seasonal cycle in either temperature, dissolved oxygen distribution or $\mathrm{pH}$ suggests that the brGDGT molecular structure is not primarily governed by membrane adaptation to changing abiotic conditions. Instead, they may result from variation in the composition of the lake's bacterial community, which, if the different bacterial taxa produce different brGDGTs, will result in different brGDGT assemblages at different times. This was also observed in the deep and meromictic Lake Lugano (Switzerland), where compositional changes in brGDGTs with depth are strongly related to bacterial community changes across the oxycline (Weber et al., 2018).

The producers of aquatic brGDGTs in Lake Chala can potentially be identified by comparing the depth distribution and temporal variation of individual brGDGTs with $16 \mathrm{~S}$ rRNA gene data obtained from the same SPM samples, following the approach of Weber et al. (2018) and Sollai et al. (2019). The only mesophilic bacteria currently known to produce the assumed precursor lipids for brGDGTs, namely iso-diabolic acid and its 5- and 6-methylated derivatives, are Acidobacteria (Sinninghe Damsté et al., 2011a, 2018). However, their presence has only been demonstrated in soil- 
derived aerobic Acidobacterial strains belonging to SDs 1, 3, 4, and 6, while strains of SDs 8,10 and 23 do not contain these lipids. Ether-bound iso-diabolic acid and its derivatives occur only in high abundance in SD4 (Sinninghe Damsté et al., 2011a, 2018). Small amounts of ether-bound iso-diabolic acid and its derivatives, including brGDGT Ia, have been detected in two Acidobacteria SD1 species isolated from soil. So far, only SD4 species have been shown to produce 5methyl iso-diabolic acid derivatives, whereas the other SDs formed 6-methyl iso-diabolic acids. This suggested that the position of methylation of iso-diabolic acid may be controlled by phylogenetic affiliations within the Acidobacteria and thus may not be a direct response to ambient environmental conditions (Sinninghe Damsté et al., 2018). Only little is known about the occurrence and diversity of Acidobacteria in lakes (e.g. Zimmermann et al., 2012; Parfenova et al., 2013; Preheim et al., 2016), but the concentrations of some individual brGDGTs in Lake Lugano at one instance during the seasonal cycle (in contrast to the prolonged monthly sampling realized here) showed a strong empirical correlation $\left(R^{2}>0.56\right)$ with the abundance of certain Acidobacteria SDs (i.e. 3, 5, 6, 8, 15, 17, 21; Weber et al., 2018).

In our data from Lake Chala, individual brGDGTs are only modestly correlated with Acidobacteria SDs (Fig. 8a). Surprisingly, whereas in Lake Chala the concentration of brGDGTs Ib and IIb correlates with the abundance of SD21 Acidobacteria, in Lake Lugano this same SD correlates instead with the concentrations of brGDGTs IIa, IIIa and IIIa" (Weber et al., 2018). The weaker correlation observed in Lake Chala may be partly due to the method of analysis; in contrast to the studies of Weber et al. (2018) and Sollai et al. (2019), we determined the sum of core and intact polar lipid-derived individual brGDGTs rather than the intact polar lipids separately. Intact polar lipids are generally considered to be better markers for "live" bacteria because the polar head group is thought to be lost quickly after cell death (White et al., 1979; Harvey et al., 1986). However, given the overall low abundance of Acidobacterial 16S rRNA sequences in Lake Chala SPM (on average $0.2 \%$ of total prokaryotes, with values up to $6 \%$ ), the omnipresence and high concentrations of brGDGTs (Fig. 4), and the mostly weak correlation between them, it seems unlikely that Acidobacteria are the predominant producers of brGDGTs in Lake Chala.

To investigate alternative bacterial sources for the brGDGTs, we also correlated their individual concentrations with those of the bacterial taxa identified in the SPM (Fig. 8b). Although empirical co-occurrence of brGDGTs and microbial taxa alone does not suffice to reveal the exact source organism(s) of those brGDGTs, the detected phyla might either contain brGDGT-producing organisms or be associated with similar habitats. For example, correlation of brGDGT Ib and IIb with the Actinobacteria phylum may be indicative of the depth habitat or growth season of the organism producing these specific brGDGTs. Our broad brGDGT16S rRNA data comparison clusters different groups of
brGDGTs, and can broadly be defined as Ib + IIb, non-cyclic 5-methyl brGDGTs, and 6-methyl brGDGTs, which all relate to a different bacterial composition (Fig. 8b). The clustering is consistent with the spatio-temporal alternation of brGDGTs Ib + IIb and IIa ${ }^{\prime}+$ IIIa' $^{\prime}$ observed in the water column of Lake Chala (Fig. 4) and suggests that these different brGDGTs (i.e. 5-methyl vs. 6-methyl, and cyclic vs. noncyclic brGDGTs) may be produced by different (groups of) bacteria. Despite our extensive SPM dataset, it is at this stage not possible to determine exactly which aquatic bacteria produce the brGDGTs in Lake Chala, but the higher correlations with bacterial taxa other than Acidobacteria suggests that an exclusive origin of lacustrine brGDGTs by Acidobacteria is deemed unlikely, in agreement with earlier work (Weber et al., 2018).

\subsection{Congruence between brGDGT distributions in SPM and settling particles}

It was previously noted that Lake Chala SPM is deprived of terrestrial biomarkers (van Bree et al., 2018), whereas they do occur in the lake's bottom sediments (e.g. Sinninghe Damsté et al., 2011b). Since the brGDGTs associated with SPM appear to be produced within the water column, a possible contribution of soil-derived brGDGTs to the lake sediments may be recognized in settling particles collected monthly in the sediment trap at $35 \mathrm{~m}$, which represents a depth- and time-integrated signal of the upper water column (although the trap is located above the predominant zone of aquatic brGDGT production; Fig. 4). The 53-month sediment-trap record fully encompasses our 17-month SPM time series and thus enables direct comparison between the datasets. Notably, the brGDGT distribution in sediment-trap material is highly similar to that in the SPM, both during the overlapping time period and averaged over the 53-month interval, and dissimilar from the brGDGT distribution in catchment soils (Figs. 5a and 6e). It thus appears that the vast majority of brGDGTs in particles settling through the water column also has an aquatic origin, and consequently can be expected to show the same temporal trends as the brGDGTs in SPM. Indeed, the observed alternation in the summed fractional abundances of brGDGTs Ib + IIb vs. $\mathrm{IIa}^{\prime}+\mathrm{IIIa}^{\prime}$ in SPM can also be recognized in the settling particles (Fig. 7d-e). Onset of upper water column stratification is marked by the relative increase of one of these two groups: the fractional abundance of $\mathrm{IIa}^{\prime}+\mathrm{IIIa}^{\prime}$ increased sharply at the onset of stratification in late 2010, 2012 and 2014, whereas those of $\mathrm{Ib}+\mathrm{IIb}$ increased in late 2011 and 2013. The similar behaviour of brGDGTs in SPM and settling particles is also reflected in the PCA including both sample series (Fig. 6e), where PC1 separates 5- and 6-methyl brGDGTs resulting from the temporal alternation of $\mathrm{Ib}+\mathrm{IIb}$ and $\mathrm{IIa}^{\prime}+\mathrm{IIIa}^{\prime}$. Although it is not clear which environmental variable controls the predominance of either group in any single year, this pattern supports our suggestion that changing brGDGT distributions in Lake Chala 
primarily reflect distinct seasonal and inter-annual variation in the composition of its aquatic microbial community rather than a physiological response in a compositionally stable resident community.

Notwithstanding their apparently similar dynamics, the sediment-trap and SPM time series are not fully equivalent. The brGDGTs in settling particles are supposedly produced in the upper $35 \mathrm{~m}$ of the water column, and indeed mostly plot with the SPM abovetrap samples in the PCA (Fig. 6e). However, for the overlapping 17-month period, the timeintegrated brGDGT distribution in sediment-trap material appears more similar to the abundance-weighted, depth- and time-integrated brGDGT signal in SPM from the mostly anoxic water column below the sediment trap $(>35 \mathrm{~m})$ than to that of the more oxic upper water column $(<35 \mathrm{~m}$; Fig. 5a-b). This suggests that a substantial contribution of brGDGTs to the sediment trap may occur during periods when the oxycline is situated well above $35 \mathrm{~m}$. In addition, material from deeper water layers can also reach the sediment trap during mixing episodes (reaching down to ca. 40$45 \mathrm{~m}$ in 2014, and to as much as $60 \mathrm{~m}$ in other years; Verschuren et al., 2009).

Temporal variation in brGDGT concentrations in the Lake Chala SPM appears to respond mainly to the seasonal cycle of stratification and mixing (Fig. 4). This pattern is not reflected in the 4.5-year sediment-trap record, where fluxes of both settling particles as a whole and brGDGTs do not show a clear, recurring annual pattern (Fig. 7a-b). Substantial temporal variation in the total flux and distribution of brGDGTs in Lake Chala has been reported previously, based on analysis of settling particles collected monthly between November 2006 and August 2010 (Sinninghe Damsté et al., 2009; Buckles et al., 2014). This contrasts with findings from sediment-trap studies in northern temperate lakes (e.g. Loomis et al., 2014b; Miller et al., 2018), where brGDGT distributions in settling particles remain relatively stable despite large seasonal variation in their fluxes. Aside from the large temporal variation in brGDGT distributions in Lake Chala, the whole of our 17-month SPM sampling period and the period from September 2013 to September 2014 in particular, stands out in the 53-month sediment-trap record due to the relatively high flux of 5-methyl brGDGTs with rings $(\mathrm{Ib}+\mathrm{IIb})$, and relatively low flux of 6-methyl brGDGTs $\left(\mathrm{IIa}^{\prime}+\mathrm{IIIa}^{\prime}\right)$ (Fig. 7d-e). The relatively large contribution of 5-methyl brGDGTs during this period is reflected in low $\mathrm{IR}_{6 \mathrm{ME}}$ values $(<0.7)$, otherwise uncommon in the entire 53month time series (Fig. 7c). Notably, this 13-month period of low $\mathrm{IR}_{6 \mathrm{ME}}$ is also characterized by the near-absence of terrestrial plant biomarkers in the SPM (van Bree et al., 2018), which may indicate that this distinct brGDGT signature is representative of a primarily aquatic source of the brGDGTs. Indeed, any contribution of soil-derived brGDGTs would be revealed by increased abundance of brGDGT-Ia, the dominant brGDGT in Chala catchment soils (Buckles et al., 2014; Fig. 5a). However, the fractional abundance of brGDGT-
Ia remains relatively stable over the entire 53-month study period (Fig. 7f), implying that the vast majority of the brGDGTs in the sediment-trap record have an aquatic origin. The caveat is that due to the mid-lake position of the sediment trap and steeply sloping crater walls, we cannot exclude the possibility for soil material to be deposited on the lake floor without reaching the sediment trap. This scenario may also explain the contrasting occurrence of terrestrial biomarkers in surficial bottom sediments and the water column (i.e. SPM) of Lake Chala.

\subsection{Discrepancy between brGDGT signatures in the water column, soils, and sediments}

The brGDGT distribution in bottom sediments of Lake Chala clearly differs from those in the SPM and settling particles, even when distributions in the latter are integrated over time and weighted-averaged (Fig. 7c-f). For example, the full range of $\mathrm{IR}_{6 \mathrm{ME}}$ values is very wide in SPM (0.35-1.00) and settling particles (0.45-1.00) whereas the three sediment samples have near-identical $\mathrm{IR}_{6 \mathrm{ME}}$ values $(\sim 0.67)$ that are substantially lower than the overall weighted-average $\mathrm{IR}_{6 \mathrm{ME}}$ of the SPM and the settling particles (Fig. 7c). In other words, over $88 \%(n=17)$ or $96.2 \%(n=53)$ of brGDGTs II and III in SPM and settling particles belong to the 6-methyl variety (Fig. $7 \mathrm{~b}$ ), whereas this is only $67 \%$ in the bottom sediment. The brGDGT fractional abundances in the sediments are also different from those in the water column, particularly those of the 5-methyl brGDGTs without cyclopentane moieties (Ia, IIa, IIIa; Figs. 5 and 7). Interestingly, the sedimentary brGDGT signature is also clearly different from that of the catchment soils (Figs. 5 and 7). Although this may be the result of mixed aquatic and soil-derived brGDGTs, this cannot explain the fractional abundances of in particular brGDGT-IIa and IIb in the sediment, which are higher than those in both the water column and the soils (Fig. 5a). These differences in brGDGT signatures in the soils, water column and the sediment suggest that additional brGDGT production may take place within the bottom sediments, as suggested previously (Buckles et al., 2014). Hence, the final brGDGT signal that is stored in Lake Chala sediments is influenced by (i) seasonal changes and substantial inter-annual variability in aquatic brGDGT production in the water column, (ii) production within the sediments, and (iii) varying proportions of aquatic and terrestrial brGDGTs over time, although the evidence for a soil contribution to Lake Chala sedimentary GDGTs remains weak.

\subsection{Implications for brGDGT-based paleoclimate reconstruction}

In order to use brGDGTs extracted from lake sediments for paleoclimate reconstruction, we need to understand how the environmental parameters of interest (primarily temperature and $\mathrm{pH}$ ) are reflected by the signal that is finally exported to 
and preserved in the sedimentary record. An earlier study of brGDGTs in time series of settling particles from Lake Chala (Buckles et al., 2014) indicated that mean annual air temperature (MAAT) was underestimated by $\sim 11-13^{\circ} \mathrm{C}$ (estimates were $14 \pm 5$ and $13 \pm 6^{\circ} \mathrm{C}$, using the East African Lake, EAL, calibrations of Tierney et al., 2010, and Loomis et al., 2012, respectively). Furthermore, maxima and minima in reconstructed temperatures from the time series of settling particles lagged the changes in air temperature by up to 5-6 months. Buckles et al. (2014) attributed these offsets to a shifted ratio of aquatic vs. soil-derived brGDGTs and also noted that the brGDGTs in Lake Chala may have a different relationship with temperature than those in the EAL calibrations. Moreover, the co-elution of 5- and 6-methyl brGDGTs in their analysis may have contributed to the observed offset. Application of the improved chromatography method (Hopmans et al., 2016) in the current study allows us to use the most recent temperature calibration based on stepwise forward selection of 5- and 6-methyl brGDGTs in the EAL dataset (MAAT ${ }_{\text {SFS }}$; Russell et al., 2018). Application of this transfer function to our sediment-trap record generates MAAT estimates between 18.5 and $25.2^{\circ} \mathrm{C}$ (on average $22.1 \pm 1.7^{\circ} \mathrm{C}$ ) and a flux-weighted overall average of $22.8^{\circ} \mathrm{C}$ (Fig. $7 \mathrm{~g}$ ). Underestimation of the observed local MAAT $\left(24.5^{\circ} \mathrm{C}\right)$ is thereby reduced to about $2{ }^{\circ} \mathrm{C}$, i.e. in the range of the calibration error of $2.1^{\circ} \mathrm{C}$.

Nevertheless, seasonal variation in reconstructed temperature based on settling particles does not seem very consistent (Fig. 7g). Whereas the highest air (and surface water) temperature occurs during the period of strong water column stratification, brGDGT-based temperature inferences peak during the periods of stratification in 2010-2011, 2013-2014 and at the end of 2014 but also during the periods of deep mixing in 2011 and 2012 (Fig. 7g). As the temporal variation in brGDGT distributions in the water column of Lake Chala appears to be linked to microbial community changes that are at best only indirectly related to temperature, this may be one reason why brGDGT signatures do not clearly track measured MMAT (Fig. 7g). On the other hand, the modestly higher temperature of the epilimnion compared to that of the lower water column (up to $\sim 4^{\circ} \mathrm{C}$, depending on the season) is reflected in a higher average reconstructed temperature for $\mathrm{SPM}_{\text {abovetrap }}\left(23.4^{\circ} \mathrm{C}, n=72\right)$ than $\mathrm{SPM}_{\text {belowtrap }}$ $\left(21.5^{\circ} \mathrm{C}, n=71, p<0.01\right.$; Fig. $\left.7 \mathrm{~g}\right)$. Similarly, the decrease of lake-water pH with depth (Wolff et al., 2014; van Bree et al., 2018) is reflected by higher reconstructed $\mathrm{pH}$ for the lake surface water (on average 8.5 at $0 \mathrm{~m}$ ) than that of deeper water layers (on average 8.1 at $80 \mathrm{~m} ; p<0.01$ ). The elevated surface water $\mathrm{pH}$ that may be expected to occur during peak primary productivity in the mixing season also appears to be recorded by brGDGTs in settling particles (8.1 during mixing $(n=16)$ vs. 7.7 during stratification $(n=37 ; p<0.02)$, even though the 53-month time series of brGDGT-inferred $\mathrm{pH}$ does not follow clear seasonal trends (Fig. 7h). Especially during the interval from September 2013 to Septem- ber 2014 that is characterized by lower $\operatorname{IR}_{6 \mathrm{ME}}$ values, the inferred $\mathrm{pH}$ is nearly constant (as is, incidentally, the observed pH; Fig. 7h). This low $\mathrm{IR}_{6 \mathrm{ME}}$ is the net result of the relative increase in cyclopentane moieties ( $\mathrm{Ib}+\mathrm{IIb}$, Fig. 7f) and decrease in the degree of isomerization (more 5-methyl brGDGTs, Fig. 7c), whereas they are both positively related to $\mathrm{pH}$ at least in global soils (Weijers et al., 2007b; De Jonge et al., 2014a). The opposite trends in the degrees of cyclization and isomerization of brGDGTs in settling particles of Lake Chala may also explain the generally weak relationship between bottom-sediment brGDGT distribution and surface water $\mathrm{pH}$ in the EAL dataset (Tierney et al., 2010; Loomis et al., 2014a; Russell et al., 2018) and supports the suggestion made by these authors that an environmental variable other than $\mathrm{pH}$ is responsible for changes in brGDGT signatures in lakes.

Notably, average MAAT and $\mathrm{pH}$ values inferred from the brGDGTs in surficial bottom sediments are yet again different from those based on brGDGTs produced in the water column and in catchment soils (Fig. 7g, h). The distinct signature of the sedimentary brGDGTs (Fig. 5a) suggests that besides an aquatic source and a potential, but unlikely, soil contribution, those brGDGTs are partly produced within the sediment. However, although brGDGT signals in lake sediments are generally, but not systematically, characterized by larger proportions of hexamethylated brGDGTs and compounds with cyclopentane moieties than those in catchment soils (Tierney and Russel, 2009; Sinninghe Damsté et al., 2009; Tierney et al., 2010; Loomis et al., 2014b; Miller et al., 2018; Guo et al., 2020), it is still not possible to determine the exact contributions of the different potential brGDGT sources to the brGDGT signature stored in the sediments of a lake. This is in contrast to rivers and the coastal marine environment, where in situ brGDGT production can be quantified on the basis of the relative abundance of 6-methyl brGDGTs (De Jonge et al., 2014b) or the weighed number of rings in the tetramethylated brGDGTs (Sinninghe Damsté, 2016). Regardless, the values of MAAT $\left(21.9^{\circ} \mathrm{C}\right)$ and $\mathrm{pH}$ (9.1) inferred from sedimentary brGDGTs in Lake Chala, as generated using the most recent EAL calibration (Russell et al., 2018), are within reasonable range of measured MAAT $\left(24.5^{\circ} \mathrm{C}\right)$ and surface water $\mathrm{pH}(9.0)$. This result is consistent with the belief that brGDGTs in lake sediments carry truthful environmental information (e.g. Tierney et al., 2010; Russell et al., 2018), albeit indirectly, and suggests that the available brGDGT-temperature calibrations already take the in situ sedimentary production into account. If this principle holds over longer timescales, it implies that we can use brGDGTs in lake sediments for paleoclimate reconstructions, even without fully understanding the mechanism that determines their signature. Nevertheless, given the lack of an obvious link between brGDGT composition (or flux) in the 53-month record of settling particles and observed MMAT indicates that sediment samples used for temperature reconstruction must integrate over multiple years. 


\section{Conclusions}

BrGDGTs in the water column of Lake Chala are primarily produced in situ. The amounts and distributions of individual aquatic brGDGT compounds are highly variable with depth and over time, and do not consistently relate to ambient temperature, $\mathrm{pH}$ or oxygen but still appear to respond to the seasonal alternation of water column mixing and stratification, which is under climatic control. The aquatic brGDGT assemblage is alternatively dominated by the compounds $\mathrm{Ib}+\mathrm{IIb}$ and $\mathrm{IIa}^{\prime}+\mathrm{IIIa}^{\prime}$, with each pair linked to the occurrence of different bacterial taxa, other than, or besides the Acidobacteria. Hence, temporal changes in brGDGT assemblages are likely due to the sequential occurrence of different groups of aquatic bacteria producing different types of brGDGTs, rather than by membrane adaptation within one group. BrGDGTs in settling particles reveal substantial interannual variation in the bacterial community of this tropical lake, superimposed on seasonal variation. Although the brGDGT distributions in SPM and settling particles from Lake Chala cannot be directly linked to local variation in air or water temperature, temporally-integrated and fluxweighted brGDGT compositions do produce reasonable temperature and surface water $\mathrm{pH}$ estimates when using the new EAL calibration of Russell et al. (2018). Regardless, the distinct brGDGT signature of surficial bottom sediments suggests that part of the sedimentary brGDGT pool is produced within the sediment itself. It thus remains crucial to discover the producers of brGDGTs and the general drivers of brGDGT production in lakes so that the uncertainties in lacustrine paleothermometry can be further constrained.

Data availability. All data are available in the Supplement and at PANGAEA: https://doi.pangaea.de/10.1594/PANGAEA.922776 (Peterse et al., 2020a; Tables S1 and S5), https://doi.pangaea.de/10. 1594/PANGAEA.922780 (Peterse et al., 2020b; Table S2), https:// doi.pangaea.de/10.1594/PANGAEA.922781 (Peterse et al., 2020c; Table S3), https://doi.pangaea.de/10.1594/PANGAEA.922783 (Peterse et al., 2020d; Table S4).

Author contributions. LGJvB, FP, DV and JSSD designed the study. LGJvB and AJB carried out brGDGT analysis. WDC interpreted water column properties. SvG and LV carried out 16S rRNA analysis. LGJvB and FP took the lead in writing with contributions of all co-authors.

Competing interests. The authors declare that they have no conflict of interest.
Acknowledgements. We thank Caxton Mukhwana Oluseno for conducting the monthly lake sampling and monitoring. We thank Araya Negash and Pauline de Regt for lipid extractions and Jan W. de Leeuw for feedback on the manuscript. We are grateful to Arnold van Dijk, Dominika Kasjaniuk, Anita van LeeuwnTolboom, and Klaas Nierop at Utrecht University and Marianne Baas, Denise Dorhout, Ellen Hopmans, Anchelique Mets, Jort Ossebaar, Sanne Vreugdenhil, and Maartje Brouwer at the Royal NIOZ for technical and analytical support. We furthermore thank Anne Roepert for help with R and Cindy De Jonge for discussions on brGDGTs. Comments of two anonymous reviewers have helped to further improve this paper. Fieldwork with collection of the studied sample materials was carried out with permission from the government of Kenya through permit 13/001/11C given to Dirk Verschuren. In accordance with National Environmental Management Authority regulations in the context of the Nagoya Protocol, DNA extracts of the analysed suspended-particulate samples are archived at the National Museums of Kenya (NMK), under voucher numbers NMK:BCT:80001 to NMK:BCT:80221. We thank Ann Mwaura and Stephen Mathai Rucina for facilitation. The raw data of the 16S rRNA gene amplicon reads were deposited in the NCBI Sequence Read Archive (SRA); BioProject number can be provided upon request. This research was supported by the NESSC Gravitation Grant (024.002.001) from the Dutch Ministry of Education, Culture and Science (OCW) and the European Research Council (ERC) under the European Union's Horizon 2020 research and innovation programme (grant agreement no. 694569 - MICROLIPIDS) both of which were given to Jaap S. Sinninghe Damsté.

Financial support. This research has been supported by the Dutch Ministry of Education, Culture and Science (OCW) (NESSC Gravitation Grant; grant no. 024.002.001) and the European Commission, H2020 Research Infrastructures (MICROLIPIDS; grant no. 694569).

Review statement. This paper was edited by Steven Bouillon and reviewed by two anonymous referees.

\section{References}

Altschul, S. F., Gish, W., Miller, W., Myers, E. W., and Lipman D. J.: Basic local alignment search tool, J. Mol. Biol., 215, 403-410, https://doi.org/10.1016/S0022-2836(05)80360-2, 1990.

Andrews, S.: A quality control tool for high throughput sequence data, available at: http://www.bioinformatics.babraham.ac.uk/ projects/fastqc/ (last access: January 2019), 2010.

Bechtel, A., Smittenberg, R. H., Bernasconi, S. M., and Schubert, C. J.: Distribution of branched and isoprenoid tetraether lipids in an oligotrophic and a eutrophic Swiss lake: insights into sources and GDGT-based proxies, Org. Geochem., 41, 822-832, https://doi.org/10.1016/j.orggeochem.2010.04.022, 2010.

Besseling, M. A., Hopmans, E. C., Boschman, R. C., Sinninghe Damsté, J. S., and Villanueva, L.: Benthic archaea as potential sources of tetraether membrane lipids in sediments across 
an oxygen minimum zone, Biogeosciences, 15, 4047-4064, https://doi.org/10.5194/bg-15-4047-2018, 2018.

Blaga, C. I., Reichart, G.-J., Vissers, E. W., Lotter, A. F., Anselmetti, F. S., and Sinninghe Damsté, J. S.: Seasonal changes in glycerol dialkyl glycerol tetraether concentrations and fluxes in a perialpine lake: Implications for the use of the TEX86 and BIT proxies, Geochim. Cosmochim. Ac., 75, 6416-6428, https://doi.org/10.1016/j.gca.2011.08.016, 2011.

Bodé, S., De Wispelaere, L., Hemp, A., Verschuren, D., and Boeckx, P.: Water-isotope ecohydrology on Mt. Kilimanjaro, Ecohydrology, 13, e2171, https://doi.org/10.1002/eco.2171, 2020.

Buckles, L. K., Weijers, J. W. H., Verschuren, D., and Sinninghe Damsté, J. S.: Sources of core and intact branched tetraether membrane lipids in the lacustrine environment: anatomy of Lake Challa and its catchment, equatorial East Africa, Geochim. Cosmochim. Ac., 140, 106-126, https://doi.org/10.1016/j.gca.2014.04.042, 2014.

Caporaso, J. G., Kuczynski, J., Stombaugh, J., Bittinger, K., Bushman, F. D., Costello, E. K., Fierer, N., Gonzales Peña, A., Goodrich, J. K., Gordon, J. I., Huttley, G. A., Kelley, S. T., Knights, D., Koenig, J. E., Ley, R. E., Lozupone, C. A., McDonald, D., Muegge, B. D., Pirrung, M., Reeder, J., Sevinsky, J. R., Turnbaugh, P. J., Walters, W. A., Widmann, J., Yatsunenko, T., Zaneveld, J., and Knight, R.: QIIME allows analysis of highthroughput community sequencing data, Nat. Methods, 7, 335336, https://doi.org/10.1038/nmeth.f.303, 2010.

Caporaso, J. G., Lauber, C. L., Walters, W. A., Berg-Lyons, D., Huntley, J., Fierer, N., Owens, S. M., Betley, J., Fraser, L., Bauer, M., and Gormley, N.: Ultra-high-throughput microbial community analysis on the Illumina HiSeq and MiSeq platforms, ISME J., 6, 1621, https://doi.org/10.1038/ismej.2012.8, 2012.

Castañeda, I. S. and Schouten, S.: A review of molecular organic proxies for examining modern and ancient lacustrine environments, Quaternary Sci. Rev., 30, 2851-2891, https://doi.org/10.1016/j.quascirev.2011.07.009, 2011.

Chevalier, M., Chase, B. M., Quick, L. J., Dupond, L. M., and Johnson, T. C.: Temperature change in subtropical southeastern Africa during the past 790,000 yr, Geology, https://doi.org/10.1130/G47841.1, online first, 2020.

Colcord, D. E., Cadieux, S. B., Brassell, S. C., Castañeda, I. S., Pratt, L. M., and White, J. R.: Assessment of branched GDGTs as temperature proxies in sedimentary records from several small lakes in southwestern Greenland, Org. Geochem., 82, 33-41, https://doi.org/10.1016/j.orggeochem.2015.02.005, 2015.

Colcord, D. E., Pearson, A., and Brassell, S. C.: Carbon isotopic composition of intact branched GDGT core lipids in Greenland lake sediments and soils, Org. Geochem., 110, 25-32, https://doi.org/10.1016/j.orggeochem.2017.04.008, 2017.

Dearing Crampton-Flood, E., Tierney, J. E., Peterse, F., Kirkels, F. M. S. A., and Sinninghe Damsté J. S.: BayMBT: A Bayesian calibration model for branched glycerol dialkyl glycerol tetraethers in soils and peats, Geochim. Cosmochim. Ac., 268, 142-159, https://doi.org/10.1016/j.gca.2019.09.043, 2020.

De Jonge, C., Hopmans, E. C., Stadnitskaia, A., Rijpstra, W. I. C., Hofland, R., Tegelaar, E. W., and Sinninghe Damsté, J. S.: Identification of novel penta- and hexamethylated branched glycerol dialkyl glycerol tetraethers in peat using HPLC-
MS, GC-MS, and GC-SMB-MS, Org. Geochem., 54, 78-82, https://doi.org/10.1016/j.orggeochem.2012.10.004, 2013.

De Jonge, C., Hopmans, E. C., Zell, C. I., Kim, J.-H., Schouten, S., and Sinninghe Damsté, J. S.: Occurrence and abundance of 6-methyl branched glycerol dialkyl glycerol tetraethers in soils: Implications for paleoclimate reconstruction, Geochim. Cosmochim. Ac., 141, 97-112, https://doi.org/10.1016/j.gca.2014.06.013, 2014a.

De Jonge, C., Stadnitskaia, A., Hopmans, E. C., Cherkashov, G., Fedotov, A., and Sinninghe Damsté, J. S.: In situ produced branched glycerol dialkyl glycerol tetraethers in suspended particulate matter from the Yenisei River, Eastern Sibera, Geochim. Cosmochim. Ac., 125, 476-491, https://doi.org/10.1016/j.gca.2013.10.031, 2014b.

Diefendorf, A. F. and Freimuth, E. J.: Extracting the most from terrestrial plant-derived $n$-alkyl lipids and their carbon isotopes from the sedimentary record: A review, Org. Geochem., 103, 121, https://doi.org/10.1016/j.orggeochem.2016.10.016, 2017.

Freeman, K. H. and Pancost, R. D.: Biomarkers for terrestrial plants and climate, in: Treatise on Geochemistry, Elsevier Inc., 2nd Edn., 395-416, 2013.

Guo, J., Glendell, M., Meersmans, J., Kirkels, F., Middelburg, J. J., and Peterse, F.: Assessing branched tetraether lipids as tracers of soil organic carbon transport through the Carminowe Creek catchment (southwest England), Biogeosciences, 17, 3183-3201, https://doi.org/10.5194/bg-17-3183-2020, 2020.

Harvey, H. R., Fallon, R. D., and Patton, J. S.: The effect of organic matter and oxygen on the degradation of bacterial membrane lipids in marine sediments, Geochim. Cosmochim. Ac., 50 , 795-804, https://doi.org/10.1016/0016-7037(86)90355-8, 1986.

Hemp, A.: Continuum or zonation? Altitudinal gradients in the forest vegetation of Mt. Kilimanjaro, Plant Ecol., 184, 27-42, https://doi.org/10.1007/s11258-005-9049-4, 2006.

Hopmans, E. C., Schouten, S., and Sinninghe Damsté, J. S.: The effect of improved chromatography on GDGT based paleoproxies, Org. Geochem., 93, 1-6, https://doi.org/10.1016/j.orggeochem.2015.12.006, 2016.

Huguet, C., Hopmans, E. C., Febo-Ayala, W., Thompson, D. H., Sinninghe Damsté, J. S., and Schouten, S.: An improved method to determine the absolute abundance of glycerol dibiphytanyl glycerol tetraether lipids, Org. Geochem., 37, 1036-1041, https://doi.org/10.1016/j.orggeochem.2006.05.008, 2006.

Lê, S., Josse, J., and Husson, F.: FactoMineR: An R package for multivariate analysis, J. Stat. Softw., 25, 1-18, 2008.

Li, J., Pancost, R. D., Naafs, B. D. A., Huan, Y., Cheng, Z., and Xie, S.: Distribution of glycerol dialkyl glycerol tetraether (GDGT) lipids in a hypersaline lake system, Org. Geochem., 99, 113-124, https://doi.org/10.1016/j.orggeochem.2016.06.007, 2016.

Loomis, S. E., Russell, J. M., and Sinninghe Damsté, J. S.: Distributions of branched GDGTs in soils and lake sediments from western Uganda: Implications for a lacustrine paleothermometer, Org. Geochem., 42, 739-751, https://doi.org/10.1016/j.orggeochem.2011.06.004, 2011.

Loomis, S. E., Russell, J. M., Ladd, B., Street-Perrott, F. A., and Sinninghe Damsté, J. S.: Calibration and application of the branched GDGT temperature proxy on East African lake sediments, Earth Planet. Sc. Lett., 357-358, 277-288, https://doi.org/10.1016/j.epsl.2012.09.031, 2012. 
Loomis, S. E., Russell, J. M., Eggermont, H., Verschuren, D., and Sinninghe Damsté, J. S.: Effects of temperature, $\mathrm{pH}$, and nutrient concentration on branched GDGT distributions in East African lakes: Implications for paleoenvironmental reconstruction, Org. Geochem., 66, 25-37, https://doi.org/10.1016/j.orggeochem.2013.10.012, 2014a.

Loomis, S. E., Russell, J. M., Heureux, A. M., D’Andrea, W. J., and Sinninghe Damsté, J. S.: Seasonal variability of branched glycerol dialkyl glycerol tetraethers (brGDGTs) in a temperate lake system, Geochim. Cosmochim. Ac., 144, 173-187, https://doi.org/10.1016/j.gca.2014.08.027, 2014b.

Loomis, S. E., Russell, J. M., Verschuren, D., Morrill, C., De Cort, G., Sinninghe Damsté, J. S., Olago, D., Eggermont, H., StreetPerrott, F. A., and Kelly, M. A.: The tropical lapse rate steepened during the Last Glacial Maximum, Sci. Adv., 3, e1600815, https://doi.org/10.1126/sciadv.1600815, 2017.

Miller, D. R., Habicht, M. H., Keisling, B. A., Castañeda, I. S., and Bradley, R. S.: A 900-year New England temperature reconstruction from in situ seasonally produced branched glycerol dialkyl glycerol tetraethers (brGDGTs), Clim. Past, 14, 16531667, https://doi.org/10.5194/cp-14-1653-2018, 2018.

Moernaut, J., Verschuren, D., Charlet, F., Kristen, I., Fagot, M., and De Batist, M.: The seismic-stratigraphic record of lake level fluctuations in Lake Challa: hydrological stability and change in equatorial East Africa over the last $140 \mathrm{kyr}$, Earth Planet. Sc. Lett., 290, 214-223, https://doi.org/10.1016/j.epsl.2009.12.023, 2010.

Naafs, B. D. A., Inglis, G. N., Zheng, Y., Amesbury, M. J., Biester, H., Bindler, R., Blewett, J., Burrows, M. A., Castillo Torres, D. D., Chambers, F. M., Cohen, A. D., Evershed, P., Feakins, S. J., Gałka, M., Gallego-Sala, A., Gandois, L., Gray, D. M., Hatcher, P. G., Honorio Coronado, E. N., Hughes, P. D. M., Huguet, A., Könönen, M., Laggoun-Défarge, F., Lähteenoja, O., Lamentowicz, M., Marchant, R., McClymont, E., Pontevedra-Pombal, X., Ponton, C., Pourmand, A., Rizzuti, A. M., Rochefort, L., Schellekens, J., De Vleeschouwer, F., and Pancost, R. D.: Introducing global peat-specific temperature and $\mathrm{pH}$ calibrations based upon brGDGT bacterial lipids, Geochim. Cosmochim. Ac., 208, 285-301, https://doi.org/10.1016/j.gca.2017.01.038, 2017a.

Naafs, B. D. A., Gallego-Sala, A. V., Inglis, G. N., and Pancost, R. D.: Refining the global branched glycerol dialkyl glycerol tetraether (brGDGT) soil temperature calibration, Org. Geochem., 106, 48-56, https://doi.org/10.1016/j.orggeochem.2017.01.009, 2017b.

Parfenova, V. V., Gladkikh, A. S., and Belykh, O. I.: Comparative analysis of biodiversity in the planktonic and biofilm bacterial communities in Lake Baikal, Microbiology, 82, 91-101, https://doi.org/10.1134/S0026261713010128, 2013.

Payne, B. R.: Water balance of Lake Chala and its relation to groundwater from tritium and stable isotope data, J. Hydrol., 11, 47-58, https://doi.org/10.1016/0022-1694(70)90114-9, 1970.

Pearson, E. J., Juggins, S., Talbot, H. M., Weckstrom, J., Rosen, P., Ryves, D. B., Roberts, S. J., and Schmidt, R.: A lacustrine GDGT-temperature calibration from the Scandinavian Arctic to Antarctic: Renewed potential for the application of GDGT paleothermometry in lakes, Geochim. Cosmochim. Ac., 75, 62256238, https://doi.org/10.1016/j.gca.2011.07.042, 2011.
Peterse, F., Kim, J.-H., Schouten, S., Klitgaard Kristensen, D., Koç, N., and Sinninghe Damsté, J.S.: Constraints on the application of the MBT/CBT palaeothermometer at high latitude environments (Svalbard, Norway), Org. Geochem., 40, 692-699, https://doi.org/10.1016/j.orggeochem.2009.03.004, 2009.

Peterse, F., Hopmans, E. C., Schouten, S., Mets, A., Rijpstra, W. I. C., and Sinninghe Damsté, J. S.: Identification and distribution of intact polar branched tetraether lipids in peat and soil, Org. Geochem., 42, 1007-1015, https://doi.org/10.1016/j.orggeochem.2011.07.006, 2011.

Peterse, F., van Bree, L. G. J., Baxter, A. J., De Crop, W., van Grinsven, S., Villanueva, L., Verschuren, D., and Sinninghe Damsté, J. S.: Concentration of branched glycerol dialkyl glycerol tetraethers and bacterial community composition in suspended particulate matter of Lake Chala from September 2013-January 2015, PANGAEA, https://doi.pangaea.de/10. 1594/PANGAEA.922776, 2020a.

Peterse, F., van Bree, L. G. J., Baxter, A. J., De Crop, W., van Grinsven, S., Villanueva, L., Verschuren, D., and Sinninghe Damsté, J. S.: Concentration of branched glycerol dialkyl glycerol tetraethers in settling particles of Lake Chala from September 2010-January 2015, PANGAEA, https://doi.pangaea.de/10. 1594/PANGAEA.922780, 2020 b.

Peterse, F., van Bree, L. G. J., Baxter, A. J., De Crop, W., van Grinsven, S., Villanueva, L., Verschuren, D., and Sinninghe Damsté, J. S.: Concentration of branched glycerol dialkyl glycerol tetraethers in catchment soils of Lake Chala, PANGAEA, https://doi.pangaea.de/10.1594/PANGAEA.922781, 2020c.

Peterse, F., van Bree, L. G. J., Baxter, A. J., De Crop, W., van Grinsven, S., Villanueva, L., Verschuren, D., and Sinninghe Damsté, J. S.: Concentration of branched glycerol dialkyl glycerol tetraethers in surficial sediments of Lake Chala, PANGAEA, https://doi.pangaea.de/10.1594/PANGAEA.922783, 2020d.

Preheim, S. P., Olesen, S. W., Spencer, S. J., Materna, A., Varadharajan, C., Blackburn, M., Friedman, J., Rodríguez, J., Hemond, H., and Alm, E. J.: Surveys, simulation and single-cell assays relate function and phylogeny in a lake ecosystem, Nat. Microbiol., 1, 16130, https://doi.org/10.1038/nmicrobiol.2016.130, 2016.

Russell, J. M., Hopmans, E. C., Loomis, S. E., Liang, J., and Sinninghe Damsté, J. S.: Distributions of 5- and 6-methyl branched glycerol dialkyl glycerol tetraethers (brGDGTs) in East African lake sediment: Effects of temperature, $\mathrm{pH}$, and new lacustrine paleotemperature calibrations, Org. Geochem., 117, 56-69, https://doi.org/10.1016/j.orggeochem.2017.12.003, 2018.

Schoon, P. L., de Kluijver, A., Middelburg, J. J., Downing, J. A., Sinninghe Damsté, J. S., and Schouten, S.: Influence of lake water $\mathrm{pH}$ and alkalinity on the distribution of core and intact polar branched glycerol dialkyl glycerol tetraethers (GDGTs) in lakes, Org. Geochem., 60, 72-82, https://doi.org/10.1016/j.orggeochem.2013.04.015, 2013.

Schouten, S., Hopmans, E. C., and Sinninghe Damsté, J. S.: The organic geochemistry of glycerol dialkyl glycerol tetraether lipids: A review, Org. Geochem., 54, 19-61, https://doi.org/10.1016/j.orggeochem.2012.09.006, 2013.

Sinninghe Damsté, J. S.: Spatial heterogeneity of sources of branched tetraethers in shelf systems: The geochemistry of tetraethers in the Berau River delta (Kalimantan, Indonesia), Geochim. Cosmochim. Ac., 186, 13-31, https://doi.org/10.1016/j.gca.2016.04.033, 2016. 
Sinninghe Damsté, J. S., Ossebaar, J., Abbas, B., Schouten, S., and Verschuren, D.: Fluxes and distribution of tetraether lipids in an equatorial African lake: constraints on the application of the $\mathrm{TEX}_{86}$ palaeothermometer and BIT index in lacustrine settings, Geochim. Cosmochim. Ac., 73, 4232-4249, https://doi.org/10.1016/j.gca.2009.04.022, 2009.

Sinninghe Damsté, J. S., Rijpstra, W. I. C., Hopmans, E. C., Weijers, J. W. H., Foesel, B. U., Overmann, J., and Dedysh, S. N.: 13,16-Dimethyl octacosanedioic acid (iso-diabolic acid): A common membrane-spanning lipid of Acidobacteria subdivisions 1 and 3, Appl. Environ. Microb., 77, 4147-4154, https://doi.org/10.1128/aem.00466-11, 2011a.

Sinninghe Damsté, J. S., Verschuren, D., Ossebaar, J., Blokker, J., van Houten, R., van der Meer, M. T. J., Plessen, B., and Schouten, S.: A 25,000-year record of climate-induced changes in lowland vegetation of eastern equatorial Africa revealed by the stable carbon-isotopic composition of fossil plant leaf waxes, Earth Planet. Sc. Lett., 302, 236-246, https://doi.org/10.1016/j.epsl.2010.12.025, 2011b.

Sinninghe Damsté, J. S., Rijpstra, W. I. C., Foesel, B. U., Huber, K., Overmann, J., Nakagawa, S., Kim, J. J., Dunfield, P., Dedysh, S., and Villanueva, L.: An overview of the occurrence of etherand ester-linked iso diabolic acid membrane lipids in microbial cultures of the Acidobacteria: Implications for brGDGT paleoproxies for temperature and $\mathrm{pH}$, Org. Geochem., 124, 63-76, https://doi.org/10.1016/j.orggeochem.2018.07.006, 2018.

Sinninghe Damsté, J. S., Hopmans, E. C., Pancost, R. D., Schouten, S., and Geenevasen, J. A. J.: Newly discovered nonisoprenoid glycerol dialkyl glycerol tetraether lipids in sediments, Chem. Comm., 17, 1683-1684, https://doi.org/10.1039/b004517i, 2000.

Sollai, M., Villanueva, L., Hopmans, E. C., Keil, R. G., and Sinninghe Damsté, J. S.: Archaeal sources of intact membrane lipid biomarkers in the oxygen deficient zone of the Eastern Tropical South Pacific, Front Microbiol., 10, 765, https://doi.org/10.3389/fmicb.2019.00765, 2019.

Sun, Q., Chu, G., Liu, M., Xie, M., Li, S., Ling, Y., Wang, X., Shi, L., Jia, G., and Lu, H.: Distributions and temperature dependence of branched glycerol dialkyl glycerol tetraethers in recent lacustrine sediments from China and Nepal, J. Geophys. Res., 116, G01008, https://doi.org/10.1029/2010JG001365, 2011.

Tierney, J. E. and Russell, J. M.: Distributions of branched GDGTs in a tropical lake system: implications for lacustrine application of the MBT/CBT paleoproxy, Org. Geochem., 40, 1032-1036, https://doi.org/10.1016/j.orggeochem.2009.04.014, 2009.

Tierney, J. E., Russell, J. M., Eggermont, H., Hopmans, E. C., Verschuren, D., and Sinninghe Damsté, J. S.: Environmental controls on branched tetraether lipid distributions in tropical East African lake sediments, Geochim. Cosmochim. Ac., 74, 49024918, https://doi.org/10.1016/j.gca.2010.06.002, 2010.

Tierney, J. E., Schouten, S., Pitcher, A., Hopmans, E. C., and Sinninghe Damsté, J. S.: Core and intact polar glycerol dialkyl glycerol tetraethers (GDGTs) in Sand Pond, Warwick, Rhode Island (USA): insights into the origin of lacustrine GDGTs, Geochim. Cosmochim. Ac., 77, 561-581, https://doi.org/10.1016/j.gca.2011.10.018, 2012.

van Bree, L. G. J., Peterse, F., van der Meer, M. T. J., Middelburg, J. J., Negash, A. M. D., De Crop, W., Cocquyt, C., Wieringa, J. J., Verschuren, D., and Sinninghe Damsté, J. S.: Seasonal variability in the abundance and stable carbon-isotopic composition of lipid biomarkers in suspended particulate matter from a stratified equatorial lake (Lake Chala, Kenya/Tanzania): Implications for the sedimentary record, Quaternary Sci. Rev., 192, 208-224, https://doi.org/10.1016/j.quascirev.2018.05.023, 2018.

Verschuren, D., Sinninghe Damsté, J. S., Moernaut, J., Kristen, I., Blaauw, M., Fagot, M., Haug, G. H., and CHALLACEA Project Members: Half-precessional dynamics of monsoon rainfall near the East African Equator, Nature, 462, 637-641, https://doi.org/10.1038/nature08520, 2009.

Volkman, J. K., Barrett, S. M., Blackburn, S. I., Mansour, M. P., Sikes, E. L., and Gelin, F.: Microalgal biomarkers: A review of recent research developments, Org. Geochem., 29, 1163-1179, https://doi.org/10.1016/S0146-6380(98)00062-X, 1998.

Weber, Y., De Jonge, C., Rijpstra, W. I. C., Hopmans, E. C., Stadnitskaia, A., Schubert, C. J., Lehmann, M. F., Sinninghe Damsté, J. S., and Niemann, H.: Identification and carbon isotope composition of a novel GDGT isomer in lake sediments: Evidence for lacustrine brGDGT production?, Geochim. Cosmochim. Ac., 154, 118-129, https://doi.org/10.1016/j.gca.2015.01.032, 2015.

Weber, Y., Sinninghe Damsté, J. S., Zopfi, J., De Jonge, C., Gili, A., Schubert, C. J., Lepori, F., Lehmann, M. F., and Niemann, H.: Redox-dependent niche differentiation provides evidence for multiple bacterial sources of glycerol tetraether lipids in lakes, P. Natl. Acad. Sci. USA, 115, 10926-10931, https://doi.org/10.1073/pnas.1805186115, 2018.

Weijers, J. W. H., Schouten, S., Hopmans, E. C., Geenevasen, J. A. J., David, O. R. P., Coleman, J. M., Pancost, R. D., and Sinninghe Damsté, J. S.: Membrane lipids of mesophilic anaerobic bacteria thriving in peats have typical archaeal traits, Environ. Microbiol., 8, 648-657, https://doi.org/10.1111/j.1462-2920.2005.00941.x, 2006.

Weijers, J. W. H., Schefuß, E., Schouten, S., and Sinninghe Damsté, J. S.: Coupled thermal and hydrological evolution of tropical Africa over the last deglaciation, Science, 315, 1701-1704, https://doi.org/10.1126/science.1138131, 2007a.

Weijers, J. W. H., Schouten, S., van den Donker, J. C., Hopmans, E. C., and Sinninghe Damsté, J. S.: Environmental controls on bacterial tetraether membrane lipid distribution in soils, Geochim. Cosmochim. Ac., 71, 703-713, https://doi.org/10.1016/j.gca.2006.10.003, 2007b.

White, D. C., Davis, W. M., Nickels, J. S., King, J. D., and Bobbie, R. J.: Determination of the sedimentary microbial biomass by extractible lipid phosphate, Oecologia, 40, 51-62, https://doi.org/10.1007/BF00388810, 1979.

Wolff, C., Haug, G. H., Timmermann, A., Sinninghe Damsté, J. S., Brauer, A., Sigman, D. M., Cane, M. A., and Verschuren, D.: Reduced interannual rainfall variability in East Africa during the Last Ice Age, Science, 333, 743-747, https://doi.org/10.1126/science.1203724, 2011.

Wolff, C., Kristen-Jenny, I., Schettler, G., Plessen, B., Meyer, H., Dulski, P., Naumann, R., Brauer, A., Verschuren, D., and Haug, G. H.: Modern seasonality in Lake Challa (Kenya/Tanzania) and its sedimentary documentation in recent lake sediments, Limnol. Oceanogr., 59, 1621-1636, https://doi.org/10.4319/lo.2014.59.5.1621, 2014.

Woltering, M., Werne, J. P., Kish, J. L., Hicks, R., Sinninghe Damsté, J. S., and Schouten, S.: Vertical and temporal variability in concentration and distribution of thaumarchaeotal tetraether lipids in Lake Superior and the implications for the application 
of the $\mathrm{TEX}_{86}$ temperature proxy, Geochim. Cosmochim. Ac., 87, 136-153, https://doi.org/10.1016/j.gca.2012.03.024, 2012.

Zhang, J., Kobert, K., Flouri, T., and Stamatakis, A.: PEAR: A fast and accurate Illumina Paired-End reAd merger, Bioinformatics, 30, 614-620, https://doi.org/10.1093/bioinformatics/btt593, 2013.

Zheng, Y., Pancost, R. D., Liu, X., Wang, Z., Naafs, B. D. A., Xie, X., Liu, Z., Yu, X., and Yang, H.: Atmospheric connections with the North Atlantic enhanced the deglacial warming in northeast China, Geology, 45, 1031-1034, https://doi.org/10.1130/G39401.1, 2017.
Zimmermann, J., Portillo, M. C., Serrano, L., Ludwig, W., and Gonzalez, J. M.: Acidobacteria in freshwater ponds at Doñana National Park, Spain, Microb. Ecol., 63, 844-55, https://doi.org/10.1007/s00248-011-9988-3, 2012. 